\title{
REVISÃO ESTRATIGRÁFICA DA PARTE ORIENTAL DA BACIA BAURU (NEOCRETACEO)
}

\author{
LUIZ ALBERTO FERNANDES ${ }^{1}$ \& ARMANDO MÁRCIO COIMBRA ${ }^{2}$
}

\begin{abstract}
STRATIGRAPHIC REVIEW OF THE EASTERN PORTION OF THE BAURU BASIN (NEOCRETACEOUS) This paper deals with the stratigraphy of the Bauru Basin based on regional investigation. The Bauru Basin was formed in the Late Cretaceous (ConiacianMaastrichtian) as a result of subsidence of the central-southern part of the South-American Platform. This inner continental basin spreads over an area of approximately $370,000 \mathrm{~km}^{2}$ and is filled by a sandy sequence with maximum thickness of 300 meters at present. Its substratum is constituted by volcanic rocks (mainly basalts) of the Serra Geral Formation (IK) from which it is separated by a regional erosive surface. The studied area, with about $180,000 \mathrm{~km}^{2}$, corresponds to the eastern part of the basin (west of São Paulo, southwest of Minas Gerais, northwest of Paraná), and is located between the coordinates $18^{\circ} \mathrm{S}$ to $25^{\circ} \mathrm{S}$ and $47^{\circ} \mathrm{W}$ to $54^{\circ} \mathrm{W}$. According to the distribution and interrelations of the units a stratigraphic revision was proposed for the basin. The Upper Cretaceous sequence is now divided in two groups, partially contemporaneous: Caiuá Group (Rio Paraná, Goio Erê and Santo Anastácio formations) and Bauru Group (Uberaba, Vale do Rio do Peixe, Araçatuba, São José do Rio Preto, Presidente Prudente, and Marília formations, including the Taiúva analcimites).
\end{abstract}

Keywords: Bauru, Caiuá, Cretaceous, basin, Stratigraphy, Brazil.

RESUMO A Bacia Bauru desenvolveu-se na parte centro-sul da Plataforma Sul-Americana, no Cretáceo Superior (ConiacianoMaastrichtiano). Como bacia continental interior, acumulou uma seqüência sedimentar essencialmente arenosa, que ocorre em área de cerca $370.000 \mathrm{~km}^{2}$. Tem por substrato basaltos da Formação Serra Geral (Ki), da qual é separada por superfície erosiva regional. O texto apresenta a revisão estratigráfica para a parte oriental da bacia, decorrente de estudos regionais, dividindo a sequiência neocretácea em dois grupos parcialmente cronocorrelatos: Caiuá (formações. Rio Paraná, Goio Erê e Santo Anastácio) e Bauru (formações Uberaba, Vale do Rio do Peixe, Araçatuba, São José do Rio Preto, Presidente Prudente e Marília, incluindo os Analcimitos Taiúva).

Palavras-chaves: Bauru, Caiuá, Cretáceo, bacia, Estratigrafia, Brasil.

\begin{abstract}
INTRODUÇÃO A Bacia Bauru formou-se no Neocretáceo, no centro-sul da Plataforma Sul-Americana, em evento de compensação isostática posterior ao acúmulo de quase $2.000 \mathrm{~m}$ de lavas basálticas, ocorrido no Cretáceo Inferior. Desenvolveu-se como bacia continental interior, pós-ruptura do continente gondwânico, acumulando uma seqüencia sedimentar essencialmente arenosa, hoje com espessura máxima de cerca de $300 \mathrm{~m}$ e área de $370.000 \mathrm{~km}^{2}$. A seqüência tem por substrato basaltos da Formação Serra Geral (Grupo São Bento), dos quais é separada por não-conformidade, e limite superior erosivo, demarcado pela Superfície Sul-Americana ou sua posterior dissecação. No Brasil, ocorre na parte ocidental do estado de São Paulo, no noroeste do Paraná, no leste e Mato Grosso do Sul, no Triângulo Mineiro e no sul de Goiás. A parte oriental da bacia, área do estudo, compreende cerca de $180.000 \mathrm{~km}^{2}$, situados entre $18^{\circ}$ e $25^{\circ} \mathrm{S}$, e $47^{\circ}$ e $55^{\circ} \mathrm{W}$ (Fig. 1).

O preenchimento da Bacia Bauru se deu em clima semi-árido a árido, entre o Coniaciano e o Maastrichtiano (Ks), intervalo definido com base na idade de fósseis de dinossauros (Huene 1939), idade absoluta de intercalações de rochas vulcânicas (Coutinho et al. 1982), e na correlação com a deposição da Formação Santos (Pereira e Feijó 1994), na Bacia de Santos.
\end{abstract}

NOVA ESTRATIGRAFIA PARA A BACIA BAURU A seqüência suprabasáltica neocretácea é formada pelos grupos Bauru e Caiuá (Fernandes \& Coimbra 1994). Redefinições de caráter litoestratigráfico propostas por Fernandes (1998) e Fernandes \& Coimbra (1998) implicaram a revisão estratigráfica para a parte oriental da Bacia Bauru (Tabela 1, Fig. 2). A alteração mais importante apresentada refere-se ao Grupo Bauru, sobretudo à Formação Adamantina. As demais unidades foram assim mantidas: Formação Uberaba conforme definição de Hasui (1968); Formação Marília na acepção de Soares et al. (1980), subdividida nos membros Echaporã, Serra da Galga e Ponte Alta (Barcelos \& Suguio 1987). Quanto ao Grupo Caiuá, adotou-se a subdivisão nas formações Santo Anastácio, Rio Paraná e Goio Erê, de Fernandes \& Coimbra (1996).

Coberturas sedimentares menos extensas, antes cartografadas a nordeste, leste e sudeste do limite principal da Bacia Bauru, foram consideradas mais antigas ou mais jovens que a seqüência neocretácea. As mais antigas são: a) arenitos e lamitos conglomeráticos dos interflúvios dos rios Pardo e Paranapanema, da região de AvaréCerqueira Cesar (SP); b) conglomerados e arenitos imaturos (diamantíferos) da região de Romaria (MG); e c) coberturas sedimentares situadas a leste do rio Araguari (MG), que repousam diretamente sobre o embasamento pré-cambriano (Grupo Araxá). As mais jovens são aquelas conhecidas como Formação Itaqueri, na acepção de Ponçano et al. (1982).

\section{CARACTERIZAÇ̃̃O DAS UNIDADES LITOESTRATIGRÁ-} FICAS Grupo Caiuá É composto pelas formações Rio Paraná, Goio Erê e Santo Anastácio. No Brasil, ocorre nos estados do Paraná, São Paulo e Mato Grosso do Sul (Fig. 1). Assenta-se sobre basaltos do Grupo São Bento e tem passagem transicional para o Grupo Bauru. Ultrapassa as fronteiras nacionais, possivelmente aflorando no extremo nordeste do Paraguai.

FORMAÇÃO RIO PARANÁ Ocorre nas partes sudoeste (principalmente) e leste do flanco oriental da bacia (SP, PR; Fig. 1). Suas melhores exposiçōes estão na margem esquerda do rio Paraná, na usina hidrelétrica Eng. Sérgio Motta (ex-Porto Primavera, SP) e no canal hidroviário de Pereira Barreto (SP). Apresenta as maiores espessuras preservadas no NW do Paraná (277 m, em Altônia; 205 m, em Terra Rica; Bigarella \& Mazuchowski 1985) e no Pontal do Paranapanema (SP). Raras vezes, expõe-se de modo contínuo (desníveis de até $200 \mathrm{~m}$ ), como nas vertentes dos morros dos Três Irmãos (Terra Rica, PR) e do Diabo (Teodoro Sampaio, SP), elevações mantidas devido à silicificação dos arenitos (Fernandes et al. 1993).

A Formação Rio Paraná tem como seção-tipo (Fernandes \& Coimbra 1994) cortes da eclusa da usina hidrelétrica Eng. Sérgio Motta, no Pontal do Paranapanema (Fig. 3a). Outras boas exposições da unidade estão no $\mathrm{km} 501$ da rod. BR 376, próximo a Paranavaí (PR); e em paredões de até $15 \mathrm{~m}$ de altura, na margem esquerda do Rio Paraná, sobretudo nas imediações de Porto São José e Porto Rico (PR), e de Presidente Epitácio (SP). Repousa diretamente sobre a Formação Serra Geral (basaltos), da qual é separada por não-conformidade. Na sua base ocorre estrato de aspecto brechóide, com até $1 \mathrm{~m}$ de espessura, constituído de arenito lamoso maciço, imaturo, com fragmentos centimétricos de basalto, nódulos de esmectita e carbonato, freqüentemente cimentados por carbonato. Tem contato lateral gradual com a Formação Goio Erê.

A Formação Rio Paraná comumente exibe notável estratificação cruzada de médio a grande porte (sets de até $10 \mathrm{~m}$ de altura), limitados por superfícies de truncamento de $2^{\mathrm{a}}$ ordem, de baixa inclinação, algumas vezes com estratos submétricos de lamitos arenosos maciços intercalados. É constituída por arenitos marrom-avermelhados a 


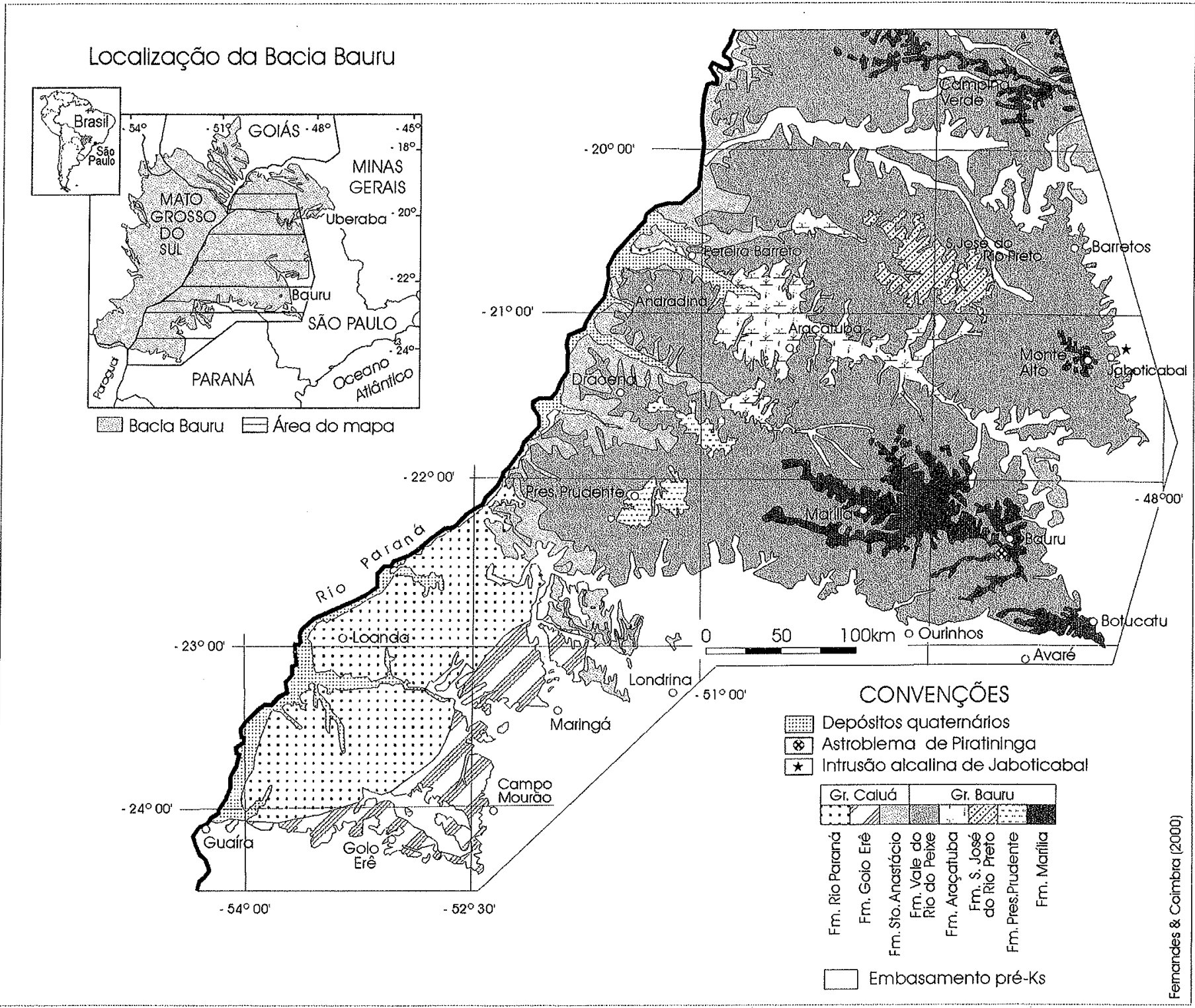

Figura I-Mapa litoestratigráfico da parte oriental da Bacia Bauru.

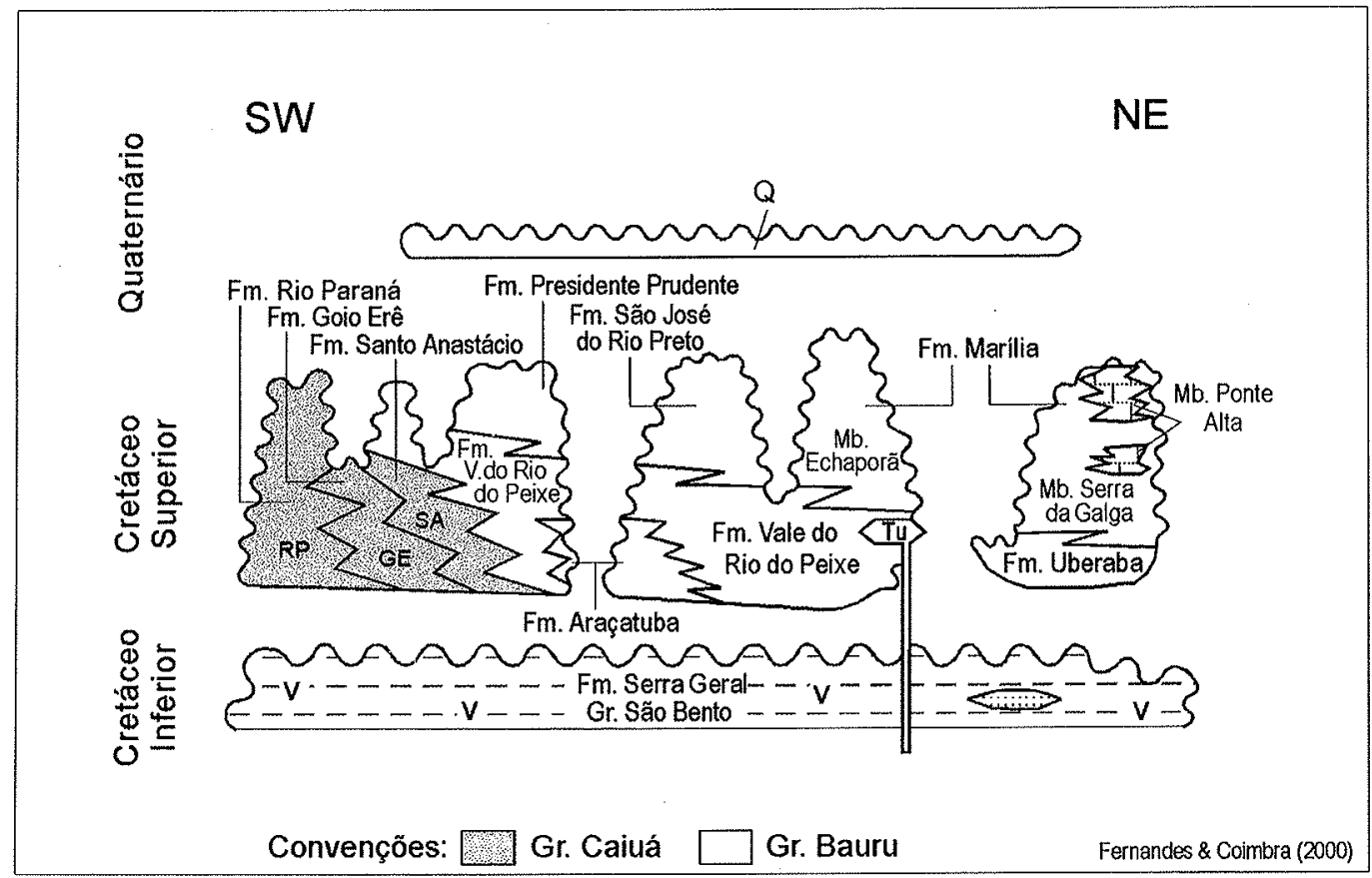

Figura 2 - Carta cronolitoestratigráfica da parte oriental da Bacia Bauru. Tu=Analcimitos Taiuva. 


\section{Grupo Caiuá}
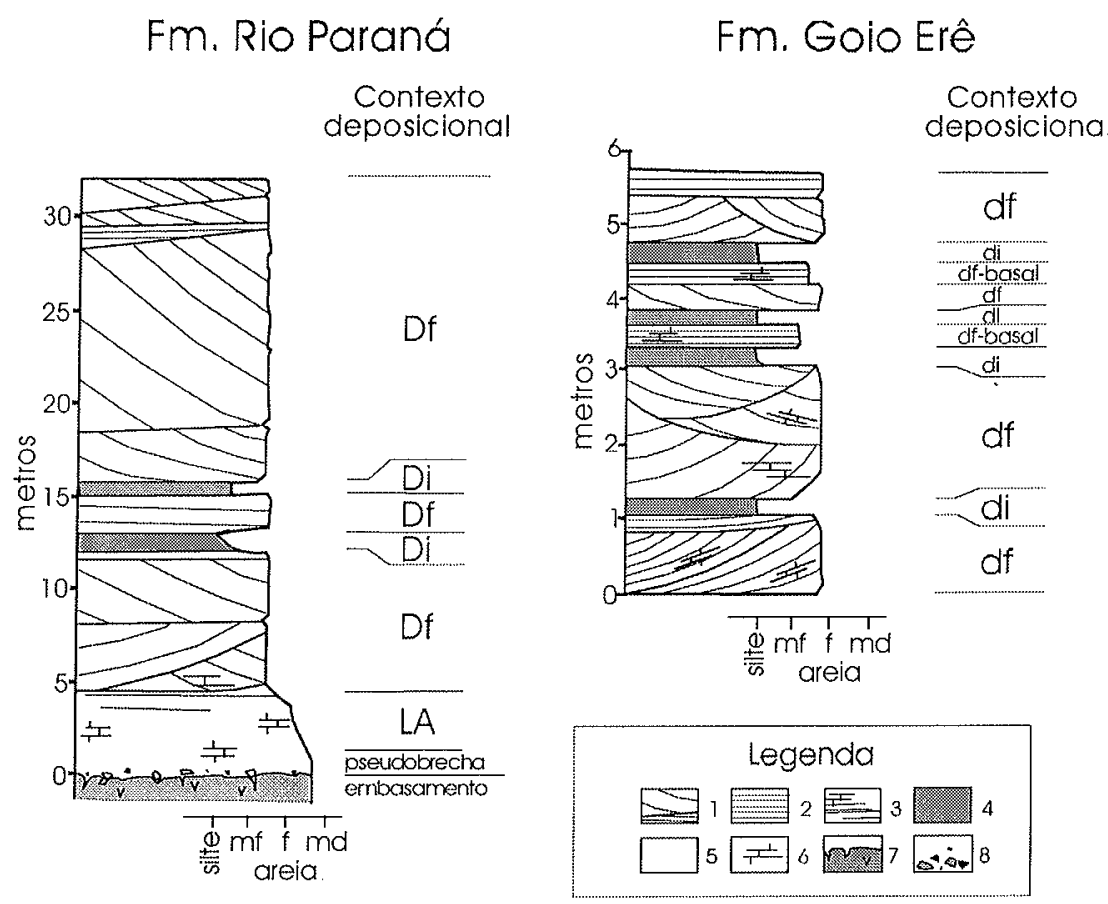

Fm. Santo Anastácio

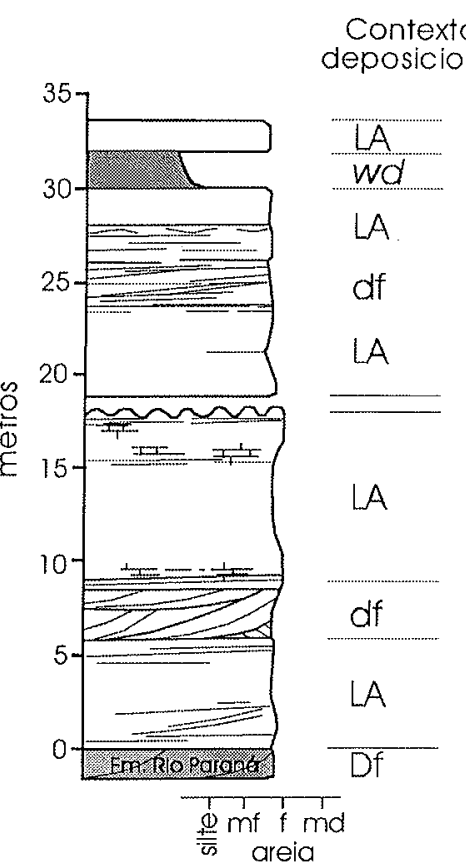

Figura 3 - Seçoes-tipo (holoestratótipos): a) Formação Rio Paraná. Eclusa da U.H.E. Eng. Sérgio Motta (ex-Porto Primavera), Pontal do Paranapanena (SP); b) Formação Goio Erê. Rod. Campo Mouräo-Goio Erê (BR 272), km 58,7; PR; c) Formação Santo Anastácio (mod. de Suguio \& Barcelos 1983). Rod. BR 158, a $2 \mathrm{~km}$ do rio Santo Anastácio, no rumo de Marabá Paulista (SP). Convenções: I arenito com estratificação cruzada, 2.arenito maciço a mal estratificado, 3.arenito com cimento e nódulos de $\mathrm{CaCO}_{3}$, 4. Lamito arenoso, 5. arenito maciço, 6. cimento CaCO ; 7.basalto, 8.arenito maciģo com fragmentos de basalto, nódulos de argila e carbonato. Depósitos: frontais de dunas de grande porte (Df), de interdunas secas (Di), frontais de dunas de pequeno-médio porte (df), de interdunas limidas (di), de lençóis de areia (LA), de wadi (wd).

Tabela 1- Nova classificaşão litoestratigráfica proposta e a correlaşão com as principais unidades anteriormente definidas.

\begin{tabular}{|c|c|c|c|}
\hline Grupo & Formação & Membro & Correspondência \\
\hline \multirow{8}{*}{ Bauru } & \multirow{3}{*}{ Marília } & Ponte Alta & Mb. Ponte Alta ${ }^{1}$ \\
\hline & & S.da Galga & Mb. Serra da Galga ${ }^{1}$ \\
\hline & & Echaporã & Mb. Echaporã ${ }^{1}$, Fm. Marília ${ }^{2}$ \\
\hline & Presidente Prudente & & Parte da Litofácies Taciba ${ }^{3}$, parte da unidade Kav (Fm. Adamantina) ${ }^{4}$ \\
\hline & S. José do Rio Preto & & Parte da Litofácies ${ }^{5}$ ou Fm. ${ }^{6}$ São José do Rio Preto \\
\hline & Uberaba & & Parte da Fm. Uberaba ${ }^{7}$ \\
\hline & Araçatuba & & $\begin{array}{l}\text { Parte da Litofácies }{ }^{5} \text { ou da Fm. }{ }^{6} \text { Araçatuba; Fm. Araçatuba }{ }^{8} \text {; parte da } \\
\text { unidade } \mathrm{Ka}_{\mathrm{III}}(\mathrm{Fm} \text {. Adamantina })^{4}\end{array}$ \\
\hline & $\begin{array}{l}\text { Vale do Rio do } \\
\text { Peixe }\end{array}$ & & $\begin{array}{l}\text { Litofácies Ubirajara }{ }^{3} \text {; parte da Litofácies }{ }^{5} \text { ou } \mathrm{Fm}{ }^{6} \text { Araçatuba; parte da } \\
\text { Litofácies Taciba }{ }^{3} \text {; unidades } \mathrm{Ka}_{\mathrm{I}}, \mathrm{Ka}_{\mathrm{II}}, \mathrm{Ka}_{\mathrm{III}} \text { e } \mathrm{Ka}_{\mathrm{IV}} \text { e parte da } \mathrm{Ka}_{\mathrm{V}} \text { (Fm. } \\
\text { Adamantina) }{ }^{4}\end{array}$ \\
\hline \multirow{3}{*}{ Caiuá } & Santo Anastácio & & Fm. Santo Anastácio ${ }^{9,3,4,10}$ \\
\hline & Rio Paraná & & Fm. Rio Paraná ${ }^{10}$ \\
\hline & Goio Erê & & Fm. Goio Erê ${ }^{10}$ \\
\hline
\end{tabular}

Definições anteriores: 1. Barcelos \& Suguio (1987), 2. Almeida \& Barbosa (1953), 3. Soares et al. (1980), 4. Almeida et al. (1980), 5. Suguio et al. (1977), 6. Suguio (1981), 7. Hasui (1968), 8. Zaine et al. (1980), 9. Stein et al. (1979), 10. Fernandes \& Coimbra (1994). 
arroxeados, finos a muito finos (raramente médios a grossos), quartzosos. Mineralogicamente são supermaturos, com boa maturidade textural. Os arenitos são bem selecionados por lâmina ou estrato, com grãos bem arredondados nas frações mais grossas, pouca matriz siltoargilosa (Fernandes et al. 1994). A maioria dos grãos exibe superfície fosca, encoberta por película ferruginosa. A rocha apresenta notável laminação ou estratificação cruzada, formada pela alternância de bandas de espessura milimétrica a centimétrica, de boa seleção interna (caráter bimodal), geradas por queda de grãos (grain fall). Em depósitos frontais de dunas podem ocorrer feições de deslizamentos por gravidade, como lentes de fluxo de grãos (grain flow), estratificação contorcida ou tabletes de arenito rotacionados (brechas de colapso). Raras vezes observam-se feições de ressecação (curled mudflakes). No Pontal do Paranapanema ocorrem dobras convolutas, de dimensões métricas, entre porções não deformadas da rocha, interpretadas como sismitos (Coimbra et al. 1992).

O seu contexto deposicional compreende construções eólicas de grande porte (draas), complexos de dunas de cristas sinuosas, amalgamadas, de região central de sand sea. A região do Pontal do Paranapanema/extremo noroeste do Paraná, onde ocorrem estratificações cruzadas de maior porte foi, provavelmente, a área central do antigo Deserto Caiuá.

FORMAÇÃO GOIO ERÊ Ocorre apenas no extremo sudeste da bacia, no estado do Paraná (Fig. 1). Suas maiores espessuras preservadas estão em torno de $50 \mathrm{~m}$. A unidade tem como seção-tipo (Fernandes \& Coimbra 1994) o corte do km 58,7 da rod. BR 272 (Fig. 3b) e seção

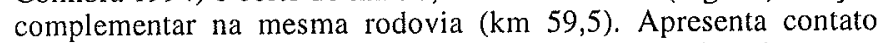
transicional com a Formação Rio Paraná e contatos erosivos (não-conformidade) com basaltos da Formação Serra Geral.

A Formação Goio Erê é composta por camadas tabulares com estratificação cruzada, alternadas com outras de aspecto maciço, às vezes com laminação plano-paralela incipiente, ondulações de adesão, climbing ripples eólicos e pequenas dobras convolutas, todas descontínuas e mal definidas. É constituída por arenitos quartzosos, marrom-avermelhados a cinza-arroxeados, finos a muito finos (ocasionalmente médios), subarcoseanos, mineralogicamente maturos e texturalmente submaturos. Os grãos têm superfície fosca, encoberta por película de óxido de ferro. É freqüente o revestimento de poros por argila autigênica (esmectita), transformada em caulinita por processos intempéricos. A cimentação carbonática é comum, localmente formando nódulos e crostas duras. Na base da unidade são comuns intercalações horizontais de arenitos maciços conglomeráticos, de até $1 \mathrm{~m}$ de espessura. São sustentadas por matriz areno-lamítica, com clastos subangulosos centimétricos de basalto e ágata, nódulos de argila e carbonato. Ocorrem nos vales dos rios Ligeiro e Goio Erê, ribeirões Tamboara e Anhumaí, a oeste-noroeste de Campo Mourão.

O seu contexto deposicional compreende depósitos de áreas periféricas de sand sea, sujeitas a oscilações do nível freático raso. Dunas eólicas de porte moderado, de cristas sinuosas, e interdunas úmidas ou aquosas.

FORMAÇÃO SANTO ANASTÁCIO Ocorre sobretudo nas calhas dos baixos vales dos afluentes do rio Paraná, em São Paulo - de modo restrito, no Paraná e em Minas Gerais -, com espessura máxima preservada de 70 a $100 \mathrm{~m}$. Tem seção-tipo no corte da rod. BR 158 , entre Presidente Venceslau e Marabá Paulista (SP; Fig. 3c). Apresenta passagens graduais e recorrentes para as formações Rio Paraná e Vale do Rio do Peixe. Onde repousa diretamente sobre basaltos da Formação Serra Geral, pode-se encontrar delgados estratos basais com fragmentos de basalto imersos em arenito imaturo, semelhantes aos da base das formações Rio Paraná e Goio Erê. A área de ocorrência da Formação Santo Anastácio contorna a da Formação Rio Paraná, para a qual passa gradualmente.

Esta formação se caracteriza por estratos arenosos tabulares, de aspecto maciço típico, com espessura decimétrica (até $1 \mathrm{~m}$ ), e raras intercalações de estratos de lamitos e argilitos. Constitui-se de arenitos quartzosos subarcoseanos, quase sempre maciços, finos a muito finos, pobremente selecionados, com a fração silte subordinada, e pequena quantidade de matriz silto-argilosa. Os grãos são subangulosos a subarredondados, foscos, encobertos por uma película de óxido de ferro.

O contexto deposicional consiste de depósitos de lençóis de areia, essencialmente secos, acumulados em extensas e monótonas planícies desérticas, marginais dos grandes complexos de dunas do sand sea (Deserto Caiuá). Mais raramente, depósitos de enxurradas de chuvas torrenciais esporádicas (wadis).

Grupo Bauru É composto pelas formações Uberaba (Hasui 1968), Vale do Rio do Peixe, Araçatuba, São José do Rio Preto, Presidente Prudente (Fernandes 1998) e Marília (Barcelos \& Suguio 1987). Inclui ainda os Analcimitos Taiúva (Fernandes \& Coimbra 1992), rochas vulcânicas localmente intercaladas na seqüência. $\mathrm{Na}$ parte oriental da bacia, ocorre em São Paulo (principalmente), no Triângulo Mineiro (MG) e no Norte do Paraná (Fig. 1). Assenta-se sobre basaltos do Grupo São Bento (Formação Serra Geral), do qual é separado por não-conformidade. Apresenta passagem gradual, lateral e recorrente, para o Grupo Caiuá.

FORMAÇÃO VALE DO RIO DO PEIXE Como unidade de maior extensão aflorante na parte leste da Bacia Bauru, constitui o substrato atual de grande parte da região oeste de São Paulo e do Triângulo Mineiro (Fig. 1). Corresponde a grande parte da antiga Formação Adamantina definida por Soares et al. (1980). Tem espessura preservada da ordem de $100 \mathrm{~m}$, medida em perfurações de poços para águas subterrâneas. A seção-tipo da Formação Rio do Peixe foi descrita no corte do $\mathrm{km} 87$ da rod. SP 457 (SW de Tupã, SP, vale do rio do Peixe, Fig. 4a). Devido à grande extensão da unidade, são sugeridas, como seções complementares, cortes de rodovia das imediações de: Mirante do Paranapanema (rod. SP 272, km 41,8, Fig. 4b), Monte Aprazível (ombreira da represa Lavínio Luchesi, Fig. 4c), Andradina (SP 300, $\sim \mathrm{km}$ 618, Fig. 4d), Olímpia (saída para Bebedouro), em São Paulo; Santo Inácio, PR (PR 317, km 83,6); Campina Verde, MG (MG 497,

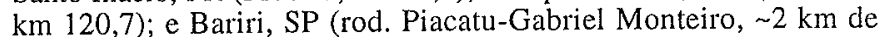
Piacatu).

A Formação Vale do Rio do Peixe repousa diretamente sobre o basaltos da Formação Serra Geral (Grupo São Bento). Passa gradualmente, a oeste e sudoeste, para a Formação Santo Anastácio, encobrindo-a. Nos médios vales dos rios Tietê, Aguapeí e S. José dos Dourados contorna - por ser em parte contemporânea - a Formação Araçatuba, recobrindo-a nos seus limites. Geralmente, este contato é gradual. Todavia, pode apresentar passagem brusca local, às vezes recorrente (Fig. 5). Nestes casos, os contatos são subhorizontais, não erosivos, e refletem o progressivo assoreamento élico do Pantanal Araçatuba, por desertificação e redução das condições paludais (Ver Formação Araçatuba). No Triângulo Mineiro a Formação Vale do Rio do Peixe ocorre apenas a oeste de uma linha que passa próxima às cidades de Uberaba e Itumbiara. Este limite coincide com a Sutura de Itumbiara, definida por Hasui \& Haralyi (1991). Para o topo, a Formação Vale do Rio do Peixe passa gradualmente para o Membro Echaporã, e tem contato marcado por diastemas com as formações Presidente Prudente e São José do Rio Preto. Transiciona gradualmente para unidades do Grupo Caiuá, no sudoeste e oeste da bacia.

A Formação Vale do Rio do Peixe é composta por estratos de espessura submétrica (geometria tabular típica), de arenitos intercalados com siltitos ou lamitos arenosos, de contatos não ou pouco erosivos. Os arenitos são muito finos a finos, marrom-claro rosado a alaranjado, de seleção moderada a boa. Têm aspecto maciço ou estratificação cruzada tabular e acanalada de médio a pequeno porte. Nos estratos "maciços" podem ocorrer zonas de estratificação/laminação plano-paralela grosseira, formadas por: a) superfícies onduladas (amplitude e comprimento de onda centimétricos), às vezes com laminação interna (climbings eólicos); b) ondulações de adesão; ou c) planos bem definidos, com lineação de partição. Localmente apresenta cimentação intensa por $\mathrm{CaCO}_{3}$. Os estratos siltosos são mais freqüentes na parte ocidental e norte dá área. Têm cores creme a marrom, estrutura maciça ou estratificação plano-paralela mal definida, fendas de ressecação (no topo, raras), ou ainda feições tubulares de diâmetro milimétrico e comprimento centimétrico, em geral verticais, no topo de estratos (preenchimento de perfurações de pequenos organismos e/ou de raízes; pouco comuns). Embora as litofácies arenosas sejam predominantes, há maior freqüência de intercalações lamíticas rumo ao vale do rio Paraná. No sudoeste da área, a Formação Vale do Rio do Peixe transiciona para unidades de ambiente desértico interior (Santo Anastácio, Goio Erê e Rio Paraná), com aumento da freqüência e do porte das intercalações com estratificação cruzada de origem eólica. $\mathrm{Na}$ borda leste - região de Matão, SP -, a formação exibe maior imaturidade textural e granulação mais grossa (arenitos finos a médios), embora 
mantenha suas características básicas (geometria e estruturas sedimentares).

O contexto deposicional consiste de depósitos essencialmente eólicos, acumulados em extensas áreas planas, na forma de lençóis de areia, com campos de dunas baixas, alternados com depósitos de loesse. Provavelmente, os lamitos foram fixados em depressões, em corpos aquosos rasos e efêmeros, criados em períodos de elevação do nível freático. No $\mathrm{km} \mathrm{59,} \mathrm{rod.} \mathrm{BR} 158$, observa-se notável contato entre depósitos de lençóis de areia, em cujo topo ocorrem seções transversais de pequenas dunas barcanas isoladas, sob estratos de loessitos. A estratificação cruzada é seccionada por superfície horizontal plana (determinada pelo antigo nível freático), acima da qual se acumularam os depósitos de loesse. Mais raramente: depósitos de enxurradas de deserto (wadis), arenosos ou conglomeráticos, e corpos aquosos efêmeros, assoreados por areias eólicas, mais comuns em posições marginais na bacia. Ocorrência restrita, no norte do Paraná, de conglomerados e arenitos conglomeráticos imaturos, ricos em ventifactos, denominada de Litofácies Mairá (Fernandes et al. 1992), interpretada como depósitos marginais de deflação. Por se tratarem de acumulações rudáceas, associadas à estratificação cruzada grosseira, Fernandes (1998) propôs reconsiderar a gênese daquelas ocorrências, para depósitos de deflação retrabalhados por enxurradas de deserto.
FORMAÇÃO ARAÇATUBA Ocorre na região de Araçatuba (SP), nos vales dos rios Tietê e Aguapeí/Feio, e seus afluentes (Fig. 1), com espessura máxima da ordem de $70 \mathrm{~m}$ (Brandt Neto 1977). Nas imediações de Tarabaí (SW de Presidente Prudente), Flora Rica (SE de Dracena) e Itajobi (SE de S. José do Rio Preto) ocorrem exposições isoladas, de pequena extensão. Sua seção-tipo situa-se no corte da rod. SP $300, \mathrm{~km}$ 548,5 (Fig. 6), próximo à cidade de Araçatuba. A designação Araçatuba foi utilizada como litofácies (Suguio et al. 1977) ou como formacão (Suguio 1981), referindo-se a partes das atuais formações Santo Anastácio e Vale do Rio do Peixe. Sua primeira seção-tipo foi informalmente proposta como membro da Forinação Adamantina, por Barcelos (1984). Seções complementares situam-se nos cortes das rod. SP 425 (km 348,7; vale do rio Aguapeí) e SP 333 (km 224, próximo à represa de Promissão). Neste último, nos limites da área de ocorrência da unidade, observam-se corpos de geometria sigmóide. A unidade repousa diretamente sobre basaltos da Formação Serra Geral. Lateralmente, interdigita-se com a Formação Vale do Rio do Peixe, que lhe encobre regionalmente. Embora bem definido (brusco), o contato entre as formações Vale do Rio do Peixe e Araçatuba é plano e sem feições de erosão do topo da unidade inferior. Seu caráter recorrente pode ser observado em vários locais, onde se manifesta como alternância das unidades, até o domínio da superior (Vale do Rio do

\section{Fm. Vale do Rio do Peixe}
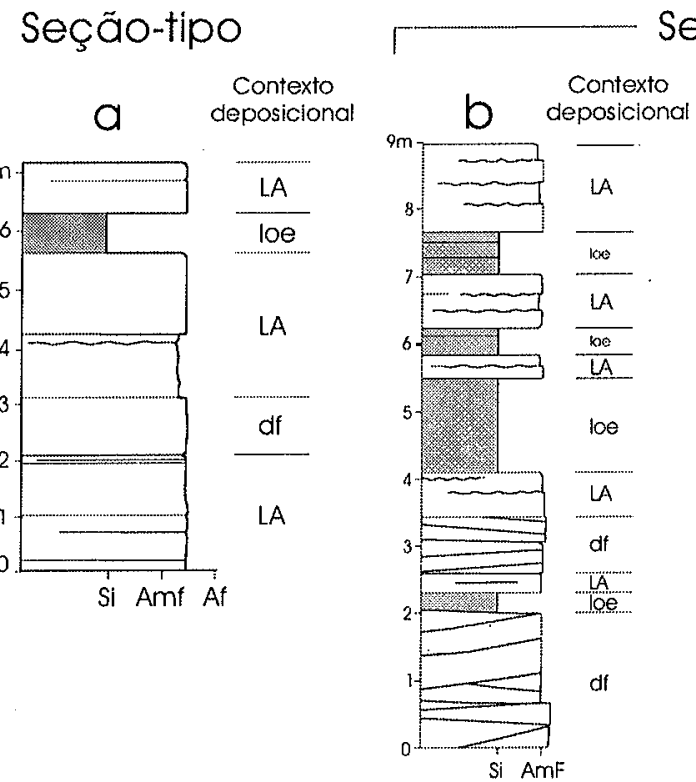

\section{Seções complementares}
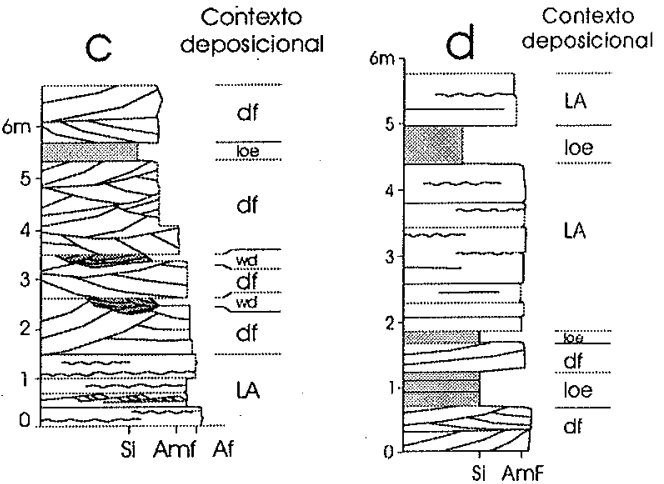

Legenda

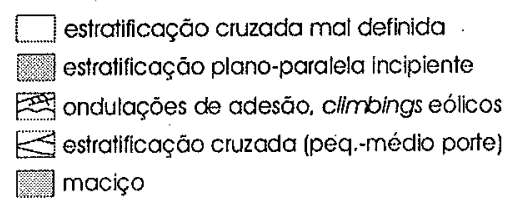

Figura 4 - Formação Vale do Rio do Peixe. Seção-tipo (holoestratótipo), rod. SP 457, km 87 (a). Seções complementares: rod. SP 272, km 41,8 (b); ombreira esquerda da Represa L.Luchesi/Monte Aprazivel, SP (c); rod. SP 300, km 618 (d). Depósitos de: lençóis de areia (LA), frontais de dunas de médio-pequeno porte (df), loesse (loe), wadi (wd).
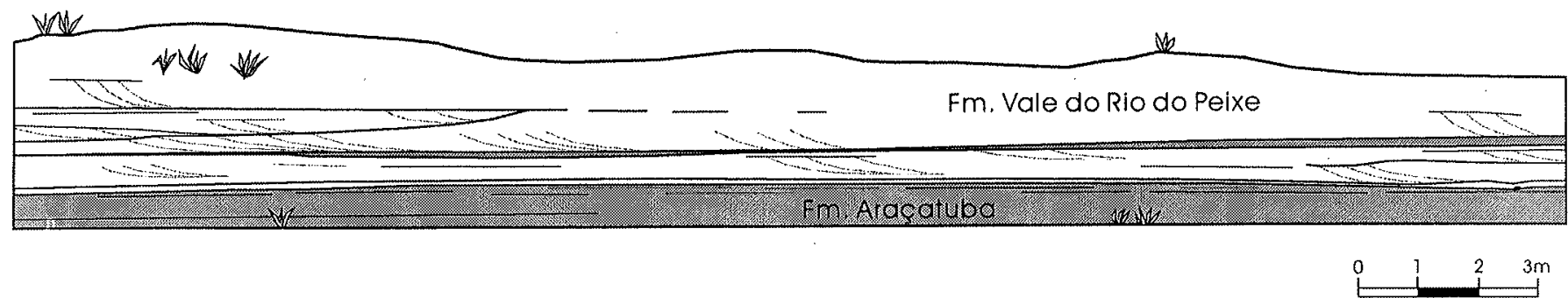

Figura 5 - Contato recorrente entre as formaşóes Araçatuba e Vale do Peixe. Notável registro do soterramento de depósitos paludais da primeira unidade por areias de dunas eólicas, da segunda. Corte da rod. SP $425, \mathrm{~km} 329$ (imediaçóes de Clementina, SP). 
Peixe). Nas suas áreas limítrofes, a Formação Araçatuba aflora nos vales em cujos interflúvios ocorre a Formação Vale do Rio do Peixe.

A Formação Araçatuba caracteriza-se por uma sucessão de estratos tabulares silto-arenosos, de aspecto maciço e espessura centimétrica a decimétrica. É constituída por siltitos e arenitos muito finos, de cor cinza-esverdeado (típica), com freqüente cimentação carbonática que pode formar crostas tabulares horizontais, paralelas à estratificação. Em espaços intergranulares verificou-se revestimento por corrensita. Ainda que em geral maciços, os estratos podem apresentar, no topo, estratificação plano-paralela, moldes e pseudomorfos de cristais fibrorradiados (gipsita), pseudomorfos de dolomita (?), gretas de ressecação e marcas de raízes. Nas bordas da área ocorrem corpos com contatos e/ou estratificação interna sigmoidal de baixa inclinação e/ou estratificação contorcida mal definida (deslizamentos subaquosos). Etchebehere et al. (1991) cadastraram ocorrências de moldes romboédricos e alguns fibrorradiados no vale do rio Tietê, a leste de Araçatuba, interpretadas como prováveis moldes de cristais de gipsita. Fernandes (1998) encontrou moldes de cristais fibrorradiados a $1 \mathrm{~cm}$ acima das marcas de raízes, indicativos de ressecação periódica. Descreveu também lâminas de pelitos com moldes de cristais, intercalados

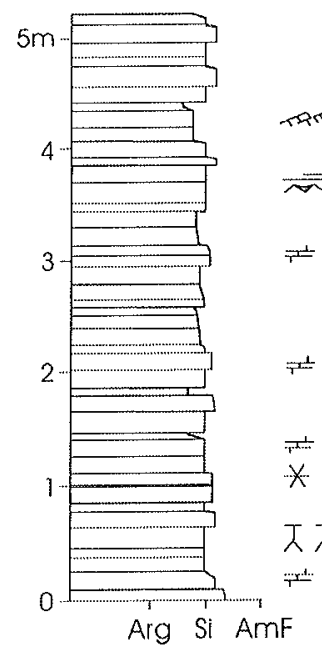

Figura 6 - Seção-tipo (holoestratótipo) da Formação Araçatuba, rod. SP 300, km 548,5.

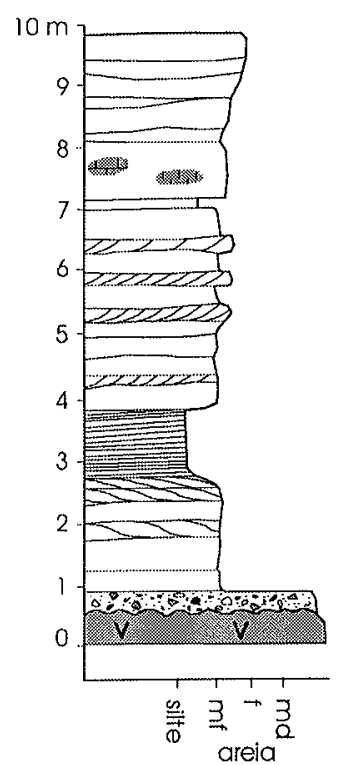

Legenda

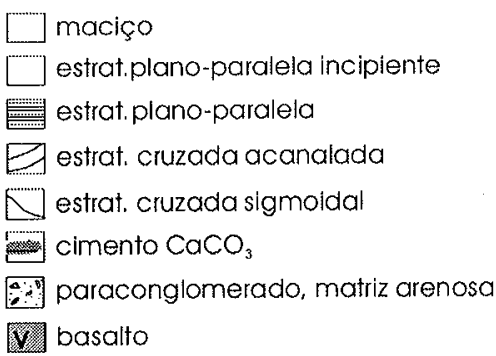

Figura 7 - Seção-tipo da Formação Uberaba. Local: ferrovia Fepasa, cruzamento com a rod. BR $050(\sim \mathrm{km} / 28)$. em siltitos com feições de fluxos trativos de regime inferior e gretas de ressecação, associação que caracteriza ambiente de águas salinas rasas, pouco agitadas, sujeitas a períodos de seca.

$O$ contexto deposicional da formação foi um ambiente paludal, de águas salinas rasas, pouco agitadas, sujeitas a períodos de exposição. A Fm Araçatuba acumulou-se em área de caráter endorrêico, baixa e alagadiça, de águas rasas e estagnadas ( $p a ̂ n t a n o$, brejo ou charco). Devido às dimensões de tal área, é mais correto denominá-la pantanal. Nas bordas do charco ocorrem depósitos de pequenos lobos deltaicos amalgamados e/ou de dunas eólicas baixas (fluidificadas devido a oscilações do nível freático). Esta geometria indica relevos originais de baixa declividade regional que contornavam a área pantanosa, comparáveis ao atual Pantanal Matogrossense, onde se registram declividades em torno de $1 \mathrm{~m} / \mathrm{km}$ (Boggiani \& Coimbra 1996). Verifica-se aumento relativo da fração areia fina, rumo à periferia da área (zona da interface borda de pântano-lençóis de areia eólicos). A freqüência de feições de ressecação (exposição, vestígios de incipiente vegetação e formação de crostas salinas) é maior na parte superior da unidade.

FORMAÇÃO UBERABA Ocorre apenas nas imediações de Uberaba, onde apresenta espessura máxima preservada de $85 \mathrm{~m}$ (Hasui 1968). Tem boas exposiçôes em cortes da ferrovia FEPASA e da rod. BR 050, nas imediações daquela cidade. A seção-tipo para a unidade (Barcelos 1984) situa-se em corte da ferrovia Fepasa, no cruzamento com a rod. BR $050(\sim \mathrm{km} \mathrm{128,4;} \mathrm{Fig.} \mathrm{7).} \mathrm{O} \mathrm{contato} \mathrm{inferior} \mathrm{da} \mathrm{Formação} \mathrm{Uberaba}$ corresponde a uma não-conformidade com basaltos da Formação Serra Geral, associado a brecha basal. É encoberta pelo Membro Serra da Galga (Formação Marília), com contato raras vezes observável.

A Formação Uberaba é uma associação de rochas epiclásticas, de seleção moderada, com notável quantidade de grãos clásticos de perovskita (composição ímpar na bacia). É formada por arenitos muito finos a lamitos siltosos, arenitos finos subordinados, com matriz argilosa. Exibe cor cinza-esverdeado a verde-oliva, típica. Ocorre em estratos tabulares e lenticulares (às vezes com limites sigmoidais) - amalgamados de modo complexo -, com intercalações subordinadas de lamitos, todos de espessura decimétrica. Exibem estrutura maciça, estratificação cruzada tabular/acanalada ou laminação plano-paralela. A unidade apresenta ainda, intercalações menos expressivas de argilitos, arenitos conglomeráticos e conglomerados de matriz arenosa. Segundo Hasui (1967) a Formação Uberaba inclui grande quantidade de materiais de retrabalhamento de rochas ígneas efusivas e

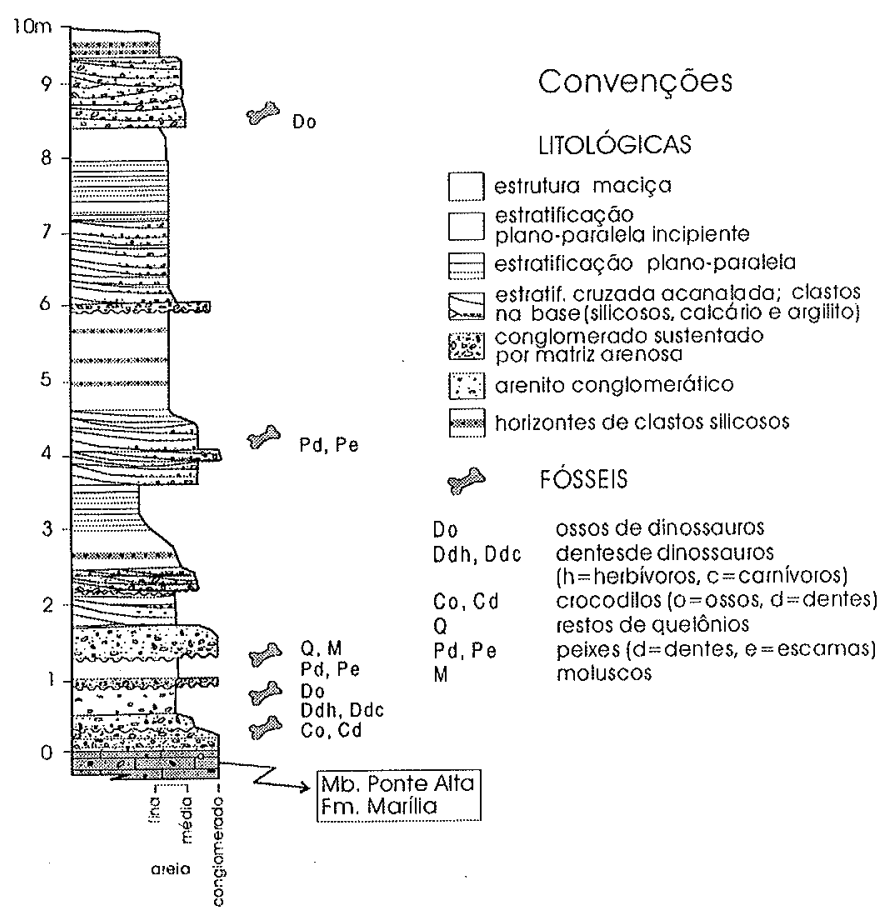

Figura 8 - Seção-tipo principal (holvestratótipo) do Membro Serra da Galga, da Formação Marilia. Local: Serra do Veadinho, imediações de Peirópolis (Uberaba, MG). Adaptado de Capilla \& Azevedo (1996). 
intrusivas básicas, ultrabásicas e intermediárias, alcalinas ou não. Os argilominerais mais frequentes na unidade são a illita (detrítica) e a esmectita (autigênica). Os arenitos são freqüentemente cimentados por $\mathrm{CaCO}_{3}$, que algumas vezes formam crostas subhorizontais.

A Formação Uberaba depositou-se em sistema fluvial entrelaçado, com predomínio de macroformas de acresção a jusante e formas de crescimento lateral restritas (Ferreira \& Castro 1996), transporte por fluxos em lençol.

FORMAÇÃO MARÍLIA Esta unidade é divida em três membros: Serra da Galga, Ponte Alta e Echaporã.

Membro Serra da Galga Ocorre apenas na borda nordeste da bacia (Triângulo Mineiro). Sua espessura máxima atual é da ordem de $110 \mathrm{~m}$ (Barbosa et al. 1970). Tem boas exposições em cortes das rodovias BR 050 e 262. O Membro Serra da Galga é formado por estratos lenticulares de arenitos e arenitos conglomeráticos, de espessura decimétrica a métrica, com freqüiente estratificação cruzada tabular a acanalada, de médio a pequeno porte. Contém ainda intercalações menos expressivas de lentes de conglomerados e lamitos.

Como seção-tipo do Membro Serra da Galga adota-se o corte da antiga caieira da Serra do Veadinho (Peirópolis), pois exibe as principais características da unidade (Fig. 5), além de constituir importante sítio paleontológico. Como seção complementar sugere-se o corte do $\mathrm{km} \mathrm{153,} \mathrm{da} \mathrm{rod.} \mathrm{BR} \mathrm{050.} \mathrm{Suguio} \mathrm{(1973)} \mathrm{apresentou} \mathrm{duas} \mathrm{seções}$ colunares para a unidade: uma na Serra da Galga (rod. BR 050, $29 \mathrm{~km}$ de Uberaba); outra na rod. BR 262 ( $25 \mathrm{~km}$ de Uberaba). Barcelos et al. (1981) apontaram-nas como representativas da Fácies Serra da Galga. Barcelos (1984) indicou informalmente aquelas duas localidades como seções-tipo do Membro Serra da Galga.

Esse membro tem contato interdigitado, complexo e irregular, com o Membro Ponte Alta. Em afloramento esta passagem corresponde a limites bem definidos (contatos bruscos), geralmente entre litotipos não cimentados (Serra da Galga) e litotipos intensamente cimentados (Ponte Alta). Tal relação é verificada, p. ex., nos cortes dos km 153 e

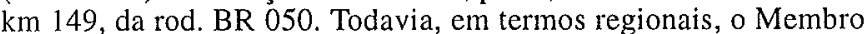
Ponte Alta tem passagens graduais para o Serra da Galga, "em todas as direções" (Goldberg 1995). Sobrepõe-se à Formação Uberaba, com a qual tem contatos pouco erosivos (diastemas). Supõe-se que passe de modo gradual para o Membro Echaporã - estratigraficamente correlato -, a oeste. Em geral, ocorre sob cobertura quaternária elúvio-coluvial arenosa, de cor avermelhada típica, que forma a parte superior dos chapadões regionais. A desagregação dos conglomerados origina, com frequiência, depósitos quaternários cascalhentos.

O Membro Serra da Galga é formado por arenitos imaturos, grossos a fínos, freqüentemente conglomeráticos, de cores amarelo pálido a avermelhado; e por lamitos de cor marrom, às vezes com clastos esparsos, imersos na matriz. Em geral, os arenitos apresentam estratificação cruzada tabular tangencial na base e acanalada, de médio a pequeno porte. Os clastos das litofácies conglomeráticas são mal selecionados, de dimensões e grau de arredondamento variados, independente de sua constituição litológica. Embora comumente centimétricos, podem medir desde alguns milímetros até $20 \mathrm{~cm}$. São constituídos de quartzo, quartzito, calcedônia, nódulos carbonáticos remobilizados, arenitos, pelitos, fragmentos de basalto e outras possíveis rochas ígneas alteradas, além de fragmentos de ossos. Localmente podem estar imbricados. São sustentados por matriz arenosa, em geral com pouca lama. Parte dos clastos são ventifactos (forma tetraédrica, faces planas e foscas). Os arenitos podem estar parcialmente cimentados por $\mathrm{CaCO}_{3}$ e, eventualmente, conter crostas de sílex de espessura centimétrica. Suguio \& Barcelos (1978) apontaram a presença de atapulgita (palygorskita) na unidade (rod. BR 050, $\mathrm{km} \mathrm{128).}$

O contexto deposicional do Membro Serra da Galga são leques aluviais medianos a distais com sistemas fluviais entrelaçados associados, e eventual alternância de depósitos de pequenas dunas eólicas (subordinados). Neste contexto, intercalam-se ainda depósitos de fluxos densos esporádicos (clastos imersos em lamitos). A ausência das litofácies rudáceas proximais típicas, a montante das áreas de ocorrência da unidade, sugere ter havido sua erosão. O Membro Serra da Galga reúne os mais importantes jazigos de ossos de répteis de grande porte da bacia (dinossauros, crocodilos e quelônios).

Membro Ponte Alta Ocorre no Triângulo Mineiro, em exposições descontínuas, numa faixa de direção NW, de pelo menos $50 \mathrm{~km}$ de extensão, que passa nos arredores de Ponte Nova e a nordeste de Uberaba, cruzando a rod. BR 050. O Membro Ponte Alta tem espessuras entre 10 e $20 \mathrm{~m}$ (Suguio et al. 1975). Suas melhores exposições são frentes de lavra de "calcário" situadas nos arredores de Ponte Alta a

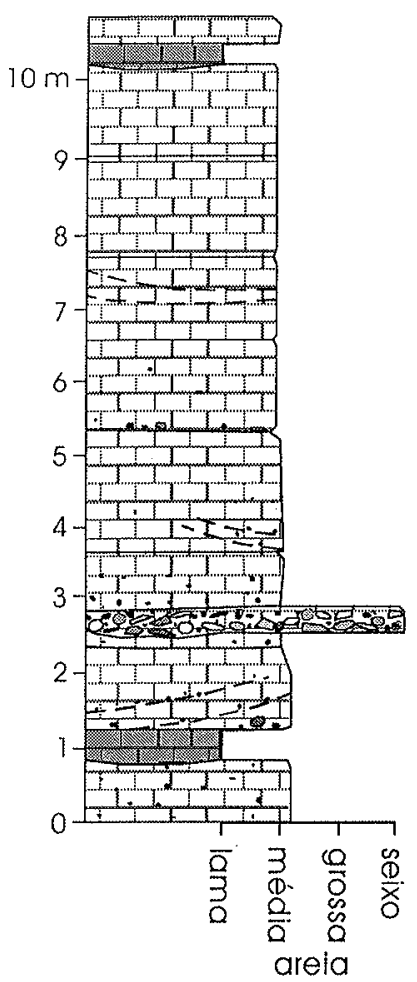

b

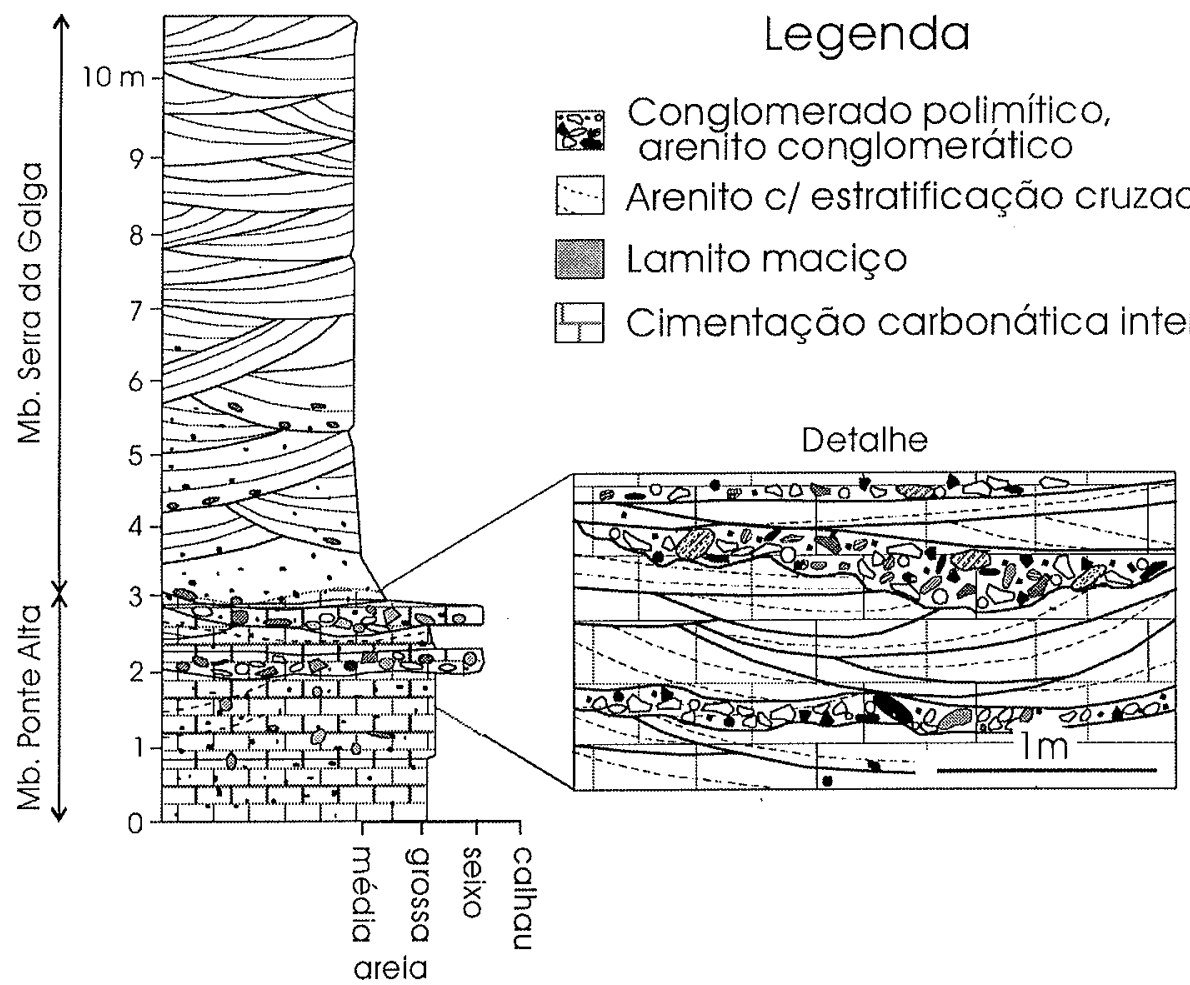

Figura 9 - a) Seção-tipo do Membro Ponte Alta. Pedreira do Lajeado, Serra do Veadinho, próxima de Peirópolis (Uberaba, MG); b) seção complementar: corte do km 153, rod. BR 050 (contato com o Membro Serra da Galga). 
(minerações Minas Oeste e Pedro Joaquim) e na rod. BR 050, entre Uberaba e Uberlândia (minerações Triângulo e Partezan).

Como seção-tipo do Membro Ponte Alta adota-se a Pedreira do Lajeado (abandonada), localizada na Serra do Veadinho, próxima de Peirópolis (Fig. 6a); e, como seção complementar, o corte do km 153 da rod. BR 050 (Fig. 6b), onde a unidade faz contato com o Membro Serra da Galga.

Os membros Ponte Alta e Serra da Galga ocorrem intimamente associados. Em perfis de sondagens (Suguio et al. 1975) o primeiro constitui intervalo estratiforme - definido por forte cimentação carbonática - no interior do segundo. Regionalmente, a passagem entre as duas unidades é gradual, por variação da intensidade de cimentação, e algumas vezes brusca. O Membro Ponte Alta constitul núcleos ou zonas tabulares interiores do Membro Serra da Galga, criados por cimentação posterior à deposição. Tal disposição concorda com o posicionamento estratigráfico da unidade Ponte Alta proposto por Goldberg \& Garcia (1995), assim como com sua gênese, de calcrete de águas subterrâneas, advogada por Silva et al. (1994). Em geral, o Membro Ponte Alta é admitido sobreposto à Formação Uberaba. Considerando-se que constiui núcleos de cimentação interiores ao Membro Serra da Galga, suas relações com a Formação Uberaba são as mesmas apresentadas por este membro.

O Membro Ponte Alta é formado por calcários impuros, designação genérica que agrupa três litotipos básicos, intensamente cimentados por carbonato de cálcio, que lhes confere aspecto geral maciço: 1) calcário arenoso de aspecto maciço, 2) calcário conglomerático de matriz arenosa (conhecidos como casco-de-burro), e 3) calcário fino fragmentado. Predominam os calcários arenosos (imaturos), que constituem corpos lenticulares a tabulares, de espessura decimétrica, algumas vezes com estruturas sedimentares - estratificação plano-paralela, prováveis gradações e feições de escavação - mascaradas pela cimentação. Os calcários conglomeráticos formam lentes, às vezes com estratificação cruzada de médio porte e base erosiva, sustentadas por matriz arenosa e arcabouço imaturos. São polimíticos (quartzo, quartzito, arenito, pelitos carbonáticos, basalto e fragmentos de outras rochas alteradas), com clastos subangulosos a subarredondados, centimétricos $(2-7 \mathrm{~cm}$; até $15 \mathrm{~cm})$. Os calcários finos têm cor levemente esverdeada e textura de mosaico (pseudobrecha), similar à estrutura agmatítica de migmatitos. Os fragmentos angulosos, de limites retilíneos, encaixam-se face-a-face. São separados por "vênulas" de cimento carbonático, formadas por crescimento expansivo (displacive). Segundo Weyl (1959, apud Watts 1978), a força de cristalização da calcita é suficiente para fraturar grãos de quartzo. As feições de deslocamento são mais comuns em minerais de clivagem pronunciada. Embora comuns nas litofácies finas, tal feição também é encontrada nas litofácies arenosas e conglomeráticas. Outra característica da unidade é a concentração local de sílica, na forma de vênulas e crostas subhorizontais (espessura centimétrica; até $20 \mathrm{~cm}$ ), assim como de revestimento (geodos) e preenchimento de pequenas cavidades. Seu modo de ocorrência sugere origem pós-sedimentar, provavelmente relacionada à formação de calcretes de águas subterrâneas. A disponibilidade de Si no sistema deve ter propiciado ainda a neoformação de palygorskita, identificada no km 149, rod. BR 050. Também são comuns fraturas preenchidas e geodos de calcita (reprecipitação).

Abstraindo-se a cimentação carbonática, que se supõe principalmente posterior, a associação de litofácies que compõe o Membro Ponte Alta sugere deposição em sistema fluvial entrelaçado (fluxos de alta energia e curta duração), de partes medianas a distais de leques aluviais marginais, a mesma do Membro Serra da Galga. Admite-se a diferenciação foi pós-sedimentar, pela formação de zonas de calcretes de águas subterrâneas (Membro Ponte Alta). Não se descarta a cimentação eodiagenética, aparentemente de menor expressão (vestígios de prováveis paleossolos e concentração de clastos em pavimentos).

Membro Echaporã Ocorre na parte superior de espigões regionais, nas margens leste e norte da bacia, sustentando planaltos regionais escarpados, digitiformes, mais expressivos nas regiões de MaríliaEchaporã e Monte Alto (SP) e de Campina Verde (MG). Tem as maiores espessuras em São Paulo, onde alcança, segundo Almeida et al. (1980), até $180 \mathrm{~m}$. Tais valores, talvez estejam superestimados, pois podem incluir a Formação Vale do Rio do Peixe (sotoposta). O Membro Echaporã teve uma seção-tipo informalmente proposta na rod. SP 333, entre Marília e Echaporã, por Barcelos (1984). Soares et al.

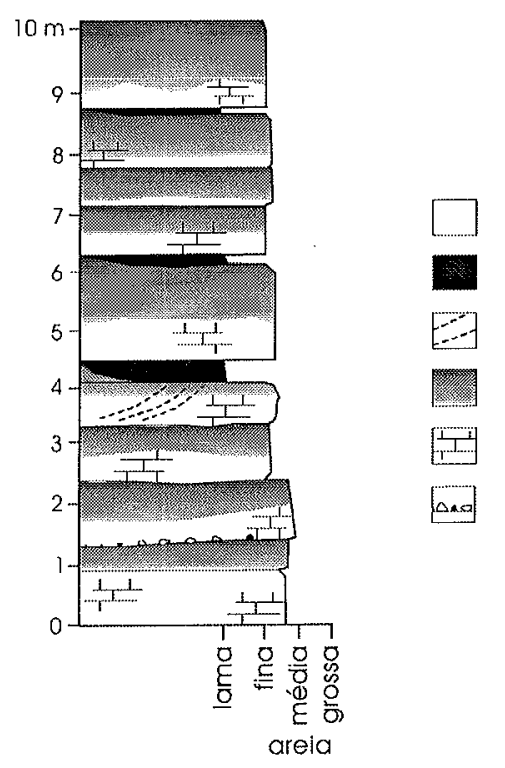

Legenda

arenito maciço

lamito arenoso maciço

estratificação cruzada

crostas duras (topo) nódulos de $\mathrm{Ca} \mathrm{CO}_{3}$ cimentação $\mathrm{CaCO}_{3}$ difusa

linha de selxos (pavimentos detríticos)

Figura 10 - Seção-tipo (holoestratótipo) do Membro Echaporã. Local: km 275 da rod. BR 153 (Serra do Mirante; SE de Marília).

(1980) definiram áreas-tipo da unidade, então tratada como Formação Marília, exposições nas regiões de Marília e Monte Alto (SP). Como seção-tipo do Membro Echaporã adota-se o corte de rodovia do $\mathrm{km}$ 275 da BR 153 (Fig. 10; Serra do Mirante; SE de Marília). Outras seções representativas são indicadas: 1) na rodovia Monte Alto-Vista Alegre, a NW de Monte Alto; e 2) na rodovia secundária de acesso no $\mathrm{km} \sim 121$ da MG 497 (Serra do Bonito, região de Campina Verde, $\mathrm{MG})$

O Membro Echaporã tem contatos graduais e interdigitados com a Formação Vale do Rio do Peixe ( $p$. ex. na margem esquerda do rio Bauru, Bauru, SP). Na borda leste, em São Paulo, repousa diretamente sobre a Formação Serra Geral (basaltos). Em Goiás, norte da bacia, ultrapassa os limites da área de exposição dos basaltos e sobrepõe-se a arenitos das formações Botucatu e Pirambóia, rochas do Grupo Passa Dois e arenitos vermelhos do Grupo Aquidauana (Fúlfaro et al. 1994).

Este membro é constituído por estratos tabulares de aspecto maciço, com espessura média em torno de $1 \mathrm{~m}$ (até $2,5 \mathrm{~m}$ ), limitados por superfícies subhorizontais planas. Algumas vezes, são compostos por subunidades amalgamadas, de lenticularidade sutil. Na base dos estratos é comum ocorrer discreta concentração de clastos. No topo, são comuns zonas de maior desenvolvimento de nódulos e crostas carbonáticas (perfil edáfico), assim como intercalações de delgadas lentes de lamitos arenosos (base côncava, topo horizontal). Em cada estrato distiguem-se, da base para o topo, zonas: de cimentação irregular difusa (nebulosa); com nódulos de formas variadas, alguns cilíndricos a cônicos; crostas duras. Compõem-se de arenitos finos a médios, imaturos, com frações grossas e grânulos em quantidades subordinadas, sobretudo nas zonas marginais da bacia. Formam estratos de aspecto maciço, de cores bege a rosa (pálidas) características, com cimentação e nódulos carbonáticos. Poucas vezes, exibem estratificação cruzada, de médio porte. As intercalações de lamitos e arenitos lamíticos têm cor marrom, espessuras centimétricas a decimétricas (até $1 \mathrm{~m}$ ), sendo mais freqüentes nas partes interiores da bacia, como a oeste de Marília. As litofácies conglomeráticas, em geral de poucos centímetros de espessura, são constituídas predominantemente por intraclastos centimétricos (carbonáticos e lamíticos); e por extraclastos silicosos (quartzo, quartzito e arenito silicificado). Estes últimos, às vezes são tetraédricos, de faces planas e foscas (ventifactos gerados na bacia ou de retrabalhamento de unidades mais antigas). Os intervalos de maior concrecionamento formam faixas de espessura decimétrica, que podem estar truncadas no topo por superfície erosiva, sobre a qual ocorre arenito conglomerático com clastos de arenito com cimento carbonático. Os argilominerais mais comuns na unidade são illita e esmectita. A cimentação carbonática posterior chega a romper clastos, por crescimento expansivo (displacive). 


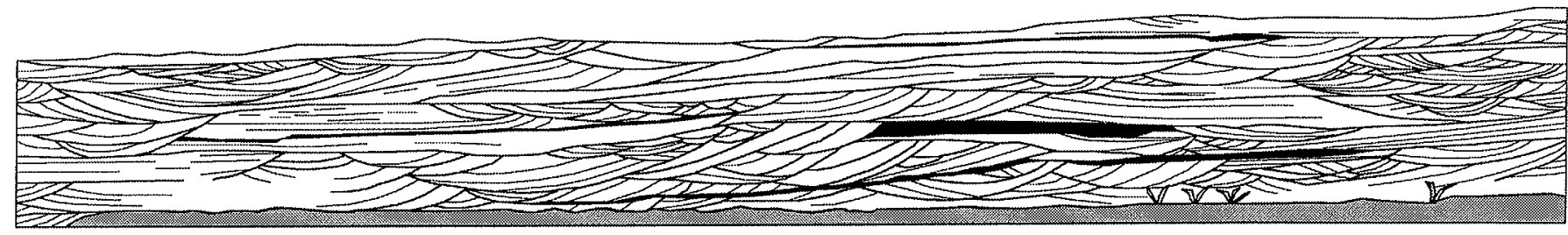

Legenda

Arenito com estratificação cruzada, às vezes conglomerático
Arenito maciço
Lamito arenoso maciço

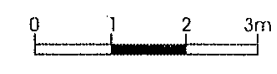

Figura 1I - Seção-tipo da Formação São José do Rio Preto (holoestratótipo). Local: rod. SP 425, sob viaduto da BR 153, entrada de São José do Rio Preto. a N7OE

ENE

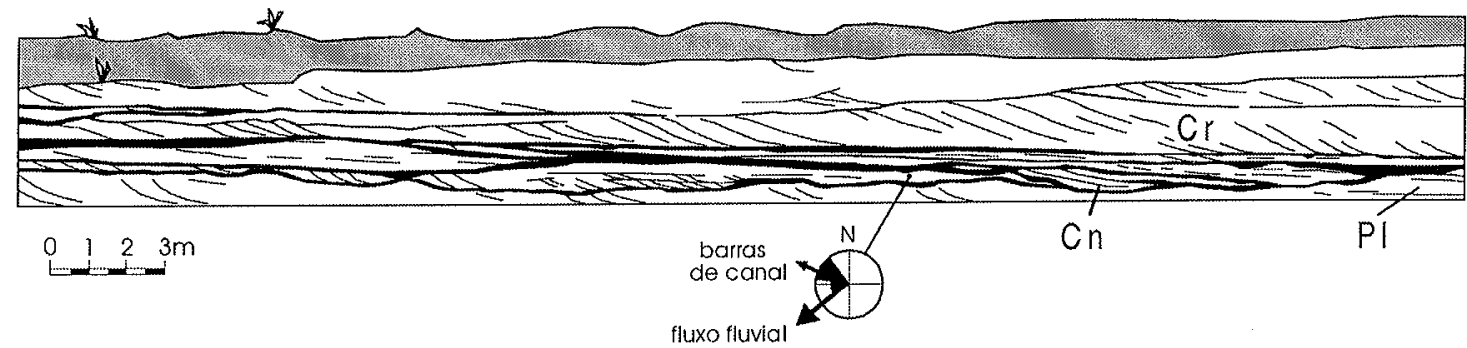

b NNW

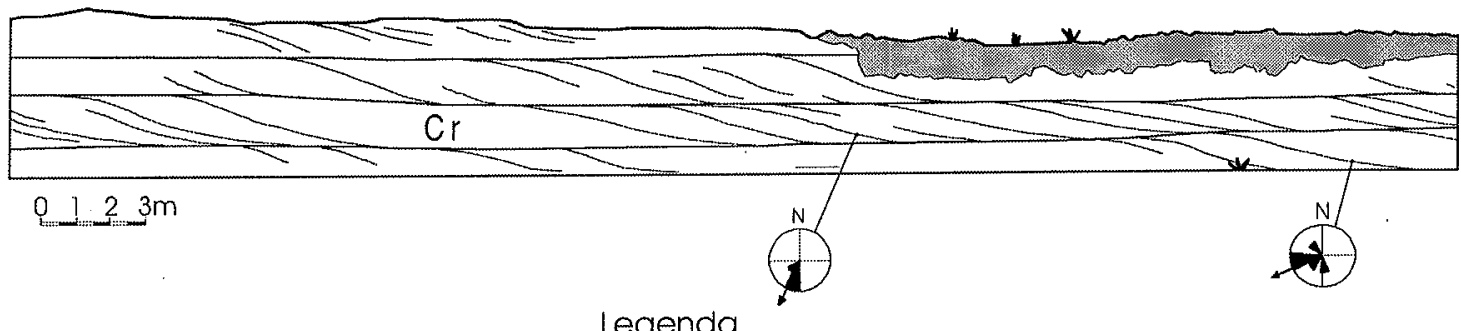

Legenda

Arenito com estratificação cruzada, às vezes conglomerático Arenito com estratificaçāo sigmoidal
E Arenito maciço

Lamito maciço

Figura 12 - a) Seção-tipo (holoestratótipo) da Formação Presidente Prudente. Depósitos de sistema fluvial meandrante arenoso: de preenchimento de canal (Cn) $e$ de planícies de inundaça (PI, Cr=crevasse). Local: rod. SP 425, km 442,4 (Presidente Prudente. SP). Escala: 1 m. b): Seção complementar (paraestratótipo). Depósitos de arrombamento de diques marginais (Cr): estratificação interna e limites (não erosivos) sigmoidais. Local: rod. BR 374, a 1,4 km do cruzamento com a SP 425 (Presidente Prudente, SP). Escala: $1 \mathrm{~m}$.

Litofácies Rubião Júnior: Tem ocorrência restrita à borda SE da bacia (imediações de Botucatu, SP). É composta por estratos arenosos lenticulares com 1 a $2 \mathrm{~m}$ de espessura, de topo plano, limitados na base por superfície de erosão, acima da qual se concentram clastos, principalmente de basalto. Os arenitos são médios a grossos, de aspecto maciço, cor marrom-rosado pálido, de seleção moderada a má, com intensa cimentação por $\mathrm{CaCO}_{3}$. A base dos estratos tem caráter conglomerático, às vezes com estratificação cruzada mal definida, de porte médio. As porções rudáceas podem formar lentes subordinadas, sustentadas por matriz arenosa média a grossa, mal selecionada. Os clastos, com até $18 \mathrm{~cm}$, são subarredondados a subangulosos, de baixa esfericidade, constituídos por basalto (dominantes), quartzo, quartzito, milonito, silexito (da Formação Estrada Nova?), geodos de quartzo, nódulos carbonáticos remobilizados (intraclastos). Para representar a Litofácies Rubião Júnior indica-se o corte do km 266,4; rod. SP 300 .
O contexto deposicional do Membro Echaporã corresponde a partes distais (saias) de leques aluviais, acumuladas por fluxos em lençol. Contém intercalações de depósitos de pavimentos detríticos de deflação e calcretes pedogenéticos, formados em intervalos de exposição. A Litofácies Rubião Júnior corresponde a depósitos mais proximais dos leques, preservados na borda sudeste da bacia. Rumo ao interior, esta litofácies passa a estratos arenosos tabulares, característicos da unidade Echaporã.

FORMAÇÃO SÃO JOSÉ DO RIO PRETO Ocorre nas cotas mais altas do interflúvio principal da região da cidade homônima, a norte do rio Tietê (Fig. 1). Tem espessura máxima de cerca de $60 \mathrm{~m}$. Sua seçãotipo situa-se no cruzamento entre as rodovias SP 425 e BR 153 (Fig. 7), em São José do Rio Preto. Sobrepõe-se à Formação Vale do Rio do Peixe, com contato transicional, localmente erosivo (diastemas). Em escala de afloramento, dificilmente se identificam superfícies de ero- 
são, provavelmente devido ao fato de ter havido a remobilização parcial de sedimentos da unidade inferior, então pouco consolidados à época da deposição da Formação S. José do Rio Preto. Na concepção ora apresentada, a Formação São José do Rio Preto corresponde a uma parte restrita da unidade anteriormente cartografada com este nome pelos autores supracitados.

A designação São José do Rio Preto foi utilizada por Suguio et al. (1977) para uma associação de fácies da antiga Formação Bauru, nos grandes interflúvios da região norte e noroeste de São Paulo. Suguio (1981) a elevou à formação, integrante do Grupo Bauru. Soares et al. (1980) mantiveram tal designação, como uma variação mais arenosa da Formação Adamantina. Barcelos (1984) indicou informalmente uma seção-tipo para o Membro São José do Rio Preto da Formação Adamantina (Soares et al. 1980), no cruzamento entre a rod. SP $310 \mathrm{e}$ a ferrovia FEPASA, em São José do Rio Preto.

A Formação S. José do Rio Preto é composta de unidades com estratificação cruzada acanalada a tabular tangencial na base, amalgamadas (padrão festonado), às vezes com intercalações subordinadas de camadas de arenitos a siltitos com estratificação plano-paralela e estruturas de fluxo aquoso de regime inferior, assim como lamitos argilosos maciços. Essencialmente, a unidade é constituída por arenitos finos a muito finos, de cores marrom-claro a bege, seleção moderada a má. São freqüentemente conglomeráticos, com frações areia média e grossa secundárias. Os clastos são nódulos carbonáticos, fragmentos de lamitos e argilitos, e seixos silicosos. Nas litofácies conglomeráticas é comum a presença de fragmentos de ossos e outros bioclastos, onde são encontradas parte do registro fossilífero da unidade, formado essencialmente por ossos e carapaças transportados. Localmente observam-se feições de bioturbação (marcas de raízes ou tubos de vermes), nas escassas litofácies lamíticas. A cimentação carbonática é comum.

A Formação São José do Rio Preto é composta por depósitos essencialmente arenosos, pouco maturos, freqüentemente conglomeráticos, acumulados em barras fluviais, de sistemas de canais entrelaçados, amplos e rasos.

FORMAÇÃO PRESIDENTE PRUDENTE Ocorre na parte superior de interflúvios dos rios do Peixe e Paranapanema (região de Presidente Prudente), assim como dos rios Aguapeí e do Peixe (espigão Osvaldo Cruz-Adamantina-Pacaembu), com boas exposições nas imediações de Presidente Prudente e Adamantina (Fig. 1). Corresponde à parte restrita da litofácies Taciba, de Soares et al. (1980). Tem espessura máxima preservada em torno de $50 \mathrm{~m}$, verificada em perfurações de poços para água subterrânea na região de Presidente Prudente.

Como seções de referência dessa unidade são indicados três cortes de rodovia, um localizado a ESE de Presidente Prudente (seção-tipo), outros dois, complementares, na parte sul da cidade. O primeiro situa-

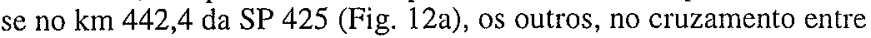
as rodovias BR 374 e SP 425 (Fig. 12b) e no km 456,4 da SP 425.

A Formação Presidente Prudente ocorre nas cotas mais altas dos interflúvios regionais, abaixo das quais aflora a Formação Vale do Rio do Peixe. $O$ contato entre elas é interdigitado, denotando a gradual instalação da primeira (depósitos fluviais) sobre a segunda (depósitos eólicos).

A Formação Presidente Prudente é constituída por arenitos muito finos a finos (dominantes) e lamitos arenosos, em alternância de: 1) lentes arenosas com estratificação cruzada acanalada, isoladas ou múltiplas (unidades de corte-e-preenchimento); 2) arenitos em corpos tabulares com estratificação sigmoidal interna; 3 ) arenitos a siltitos em camadas tabulares, com estratificação plano-paralela e estruturas de fluxo aquoso de regime inferior dominante; e 4) lamitos argilosos em geral maciços, em estratos tabulares. Os arenitos têm cores marromavermelhado claro a bege, seleção moderada a má, matriz lamítica; os lamitos argilosos têm cor marrom-escuro (chocolate). Eventualmente, a fração areia média pode ocorrer nos arenitos, em menor porcentagem. Não raro, os estratos e lentes arenosas formam "mantas" suavemente onduladas, com cimentação carbonática posterior à deformação por sobrecarga (diagenética).

Na base das feições de corte-e-preenchimento podem ocorrer estratos lamíticos gerados por processos de desaceleração de fluxo, em abandonos temporários de canal. Algumas vezes, a laminação cruzada é formada por alternância de areia e de argila, e pode conter intraclastos argilosos acomodados nos planos da laminação (canibalismo). Os estratos cruzados podem apresentar estruturação interna de laminação por migração de ondulações (climbings). As diversas superfícies internas secundárias de erosão, seladas com lama e seguidas por brechas intraformacionais, indicam frequientes flutuações de energia, indicativas de fluxos variáveis (sazonais ou efêmeros). Os intraclastos das litofácies que preenchem canais são em geral lamelares, de argilito marrom (cor chocolate), subangulosos a subarredondados, com dimensões milimétricas a centimétricas (até $6 \mathrm{~cm}$, raras vezes com $20 \mathrm{~cm}$ ). Ocorrem na parte inferior de estratos inclinados, assentados em concordância com a estratificação. Nestas litofácies podem ser encontrados ainda intraclastos carbonáticos, clastos silicosos (remobilizados) e fragmentos de ossos, todos de dimensões centimétricas.

Tabela 2 - Correspondência entre unidades litoestratigráficas e associações de fácies individualizadas na parte oriental da Bacia Bauru.

\begin{tabular}{|c|c|c|c|}
\hline Formação & Depósitos principais & Ambiente deposicional & Relaçōes de contato \\
\hline $\begin{array}{l}\text { Vale do Rio do Peixe } \\
\qquad(v p x)\end{array}$ & $\begin{array}{l}\text { Lençóis de areia, loesse e dunas eólicas } \\
\text { Wadis }\end{array}$ & Planícies de lençois de areia & $\begin{array}{l}\text { Inferior: não-conformidade com embasamento; } \\
\text { Lateral interdigitado e transgressivo con } a r \xi \text {, lateral gradual com } \\
\text { sta, goe e rpa } \\
\text { Stuperior erosivo (diastemas) com ech, srp e ppr }\end{array}$ \\
\hline $\begin{array}{c}\text { Araçatuba } \\
\left(a r_{\zeta}\right)\end{array}$ & $\begin{array}{l}\text { Paludais (pântano) } \\
\text { Lobos arenosos de borda }\end{array}$ & Pantanal & $\begin{array}{l}\text { Inferior: não-conformidade com embasamento; } \\
\text { Lateral e superior interdigitado } \operatorname{com} v p x\end{array}$ \\
\hline $\begin{array}{l}\text { Rio Paraná } \\
\quad(r p a)\end{array}$ & $\begin{array}{l}\text { Dunas eólicas de grande porte/draas } \\
\text { Interdunas úmidas }\end{array}$ & $\begin{array}{l}\text { Complexos de grandes dunas, } \\
\text { deserto interior }\end{array}$ & $\begin{array}{l}\text { Inferior: nāo-conformidade com embasamento; } \\
\text { Lateral gradual com } v p x \text {, sfa e goe }\end{array}$ \\
\hline $\begin{array}{l}\text { Goio Erê } \\
(\text { goe })\end{array}$ & $\begin{array}{l}\text { Dunas é́licas de médio/pequeno porte e } \\
\text { interdunas úmidas }\end{array}$ & $\begin{array}{l}\text { Planícies marginais de deserto, com } \\
\text { dunas médias e interdunas úmidas }\end{array}$ & $\begin{array}{l}\text { Inferior: não-conformidade com embasamento; } \\
\text { Lateral gradual com sta e rpa }\end{array}$ \\
\hline $\begin{array}{l}\text { Santo Anastácio } \\
\text { (sta) }\end{array}$ & Lençóis de areia & $\begin{array}{l}\text { Planícies de lençóis de areia, } \\
\text { periféricas de deserto }\end{array}$ & $\begin{array}{l}\text { Inferior: não-conformidade com embasamento; } \\
\text { Lateral gradual com } r p a \text { e goe, lateral e superior gradual com } v p x\end{array}$ \\
\hline $\begin{array}{c}\text { Uberaba } \\
(u b e)\end{array}$ & Barras arenosas e planicies de espraiamento & Fluvial entrelaçado & $\begin{array}{l}\text { Inferior: não-confornidade com embasamento; } \\
\text { Superior: erosivo (por diastemas) com sga/pta }\end{array}$ \\
\hline $\begin{array}{c}\text { Serra da Galga } \\
(s g a) \\
\end{array}$ & $\begin{array}{l}\text { Barras arenosas e barras cascalhentas } \\
\text { Espraiamento, lags e lagoas residuais }\end{array}$ & $\begin{array}{l}\text { Fluvial entrelaçado, distal de leques } \\
\text { aluviais }\end{array}$ & $\begin{array}{l}\text { Inferior: local mente erosivo (diastemas) com } u b e \\
\text { Lateral gradual com ech; e } \operatorname{sip} \text { (suposto) }\end{array}$ \\
\hline $\begin{array}{c}\text { Ponte Alta } \\
(p t a)\end{array}$ & $\begin{array}{l}\text { Barras arenosas, espraiamento } \\
\text { Barras cascalhentas, lags e lagoas residuais }\end{array}$ & $\begin{array}{l}\text { Fluvial entrelaçado, distal de leques } \\
\text { aluviais }\end{array}$ & $\begin{array}{l}\text { Inferior: localmente erosivo (diastemas) com ube } \\
\text { Lateral gradual com ech e srp (supostos) }\end{array}$ \\
\hline $\begin{array}{l}\text { Echaporã } \\
(e c h)\end{array}$ & $\begin{array}{l}\text { Fluxos em lençol } \\
\text { Lagoas residuais, pavimentos de deflação e } \\
\text { lagss }\end{array}$ & $\begin{array}{l}\text { Planícies de lençóis de areia, distais } \\
\text { de leques aluviais }\end{array}$ & $\begin{array}{l}\text { Inferior: não-conformidade com embasamento e transgressivo (por } \\
\text { diastemas) com } v p x\end{array}$ \\
\hline $\begin{array}{l}\text { São José do Rio Preto } \\
(s / p) \\
\end{array}$ & $\begin{array}{l}\text { Barras arenosas e planícies de espraiamento } \\
\text { Lagoas residuais }\end{array}$ & Fluvial entrelaçado & $\begin{array}{l}\text { Inferior: localmente erosivo (diastemas) com } v p x \text {; } \\
\text { Lateral gradual com sga e ppr (supostos) }\end{array}$ \\
\hline $\begin{array}{l}\text { Presidente Prudente } \\
\qquad(p p r)\end{array}$ & $\begin{array}{l}\text { Canais preenchidos, depósitos de } \\
\text { transbordamento e de arrombamento de } \\
\text { diques marginais } \\
\text { Canais de atalho (chute) }\end{array}$ & Fluvial meandrante arenoso & $\begin{array}{l}\text { Inferior: localmente erosivo (diastemas) com } v p x \text {; } \\
\text { Lateral gradual com } s r p \text { (suposto) }\end{array}$ \\
\hline
\end{tabular}


Depósitos proximais de arrombamento de diques marginais podem formar sucessões verticais de corpos arenosos, com estratificação sigmoidal de baixo ângulo, separados por superfícies basais planas não-erosivas (mantas de lobos arenosos). Seccionados em cortes transversais à direção de fluxo, estes depósitos exibem superfícies de topo levemente convexas para cima (olhos de signóide).

A Formação Presidente Prudentedepositou-se em sistema fluvial meandrante arenoso fino, de canais rasos com sinuosidade relativamente baixa. A unidade é composta pela alternância de depósitos de preenchimento de canais amplos e rasos, com depósitos de planícies de inundação/arrombamento de diques marginais (crevasse). Provavelmente, o caráter meandrante foi determinado pela baixa declividade regional das áreas mais interiores da bacia. Nas litofácies de arrombamento de diques marginais podem preservar-se esqueletos e carcaças menos desarticulados, como cascos de tartarugas.

ANALCIMITOS TAIÚVA São rochas extrusivas de natureza alcalina, de espessura máxima de $15 \mathrm{~m}$, intercaladas na porção superior Formação Vale do Rio do Peixe. Foram descritas em testemunhos de perfurações para poços de água subterrânea, da região centro norte de São Paulo (Coimbra et al. 1981, Coutinho et al. 1982). Segundo os autores, os analcimitos ocorrem em subsuperfícic, num polígono de pelo menos $100 \mathrm{~km}^{2}$, definido pela cidades paulistas de Taiúva, Piranji, Aparecida de Monte Alto, situado a noroeste de Jaboticabal. Próximo a esta última cidade foi descrito um provável pipe de rocha alcalina (Pinotti et al. 1970, Gomes \& Valarelli 1970), que Coutinho et al. (1982) associaram ao mesmo evento eruptivo, contemporâneo à sedimentação neocretácea. Os Analcimitos Taiúva têm cor marrom-claro avermelhado a amarelado, textura afanítica, e encontram-se semi-alterados por processos deutéricos. Algumas vezes, apresentam amígdalas de calcita - mineral que também preenche fraturas -, feições que reiteram o caráter vulcânico extrusivo da rocha (Coimbra et al. 1981 , Coutinho et al. 1982).

\section{LITOESTRATIGRAFIA E ALOESTRATIGRAFIA DA BACIA}

BAURU A revisão ora proposta tem caráter litoestratigráfico. Todavia, as unidades, definidas por critérios litológicos, correspondem a associaçōes (lito)faciológicas cronocorrelatas bem caracterizadas (Tabela 2). Sob a óptica dos novos conceitos de aloestratigrafia, foi exa- minada a possibilidade de tratá-las como alounidades, posto que tais, na prática, correspondem a unidades de caráter genético. Por outro lado, o Código Brasileiro de Nomenclatura Estratigráfica (Petri et al. 1986) não prevê esta forma de apresentação, a exemplo do código americano, visto que a aplicação mais extensiva de tais conceitos é relativamente recente no Brasil.

Outra dificuldade na definição de unidades aloestratigráficas em sequiências sedimentares continentais deve-se à natureza dos limites entre as grandes associações de fácies, sobretudo pelo caráter das superfícies limitantes dos conjuntos litológicos mapeáveis. O contato gradual e recorrente entre os grupos Caiuá e Bauru, por exemplo, dificulta a separação em dois alogrupos. Na Bacia Bauru não se desenvolveram superfícies discordantes de caráter regional ou horizontesguia, devido às características da sedimentação em ambientes continentais, sobretudo semi-áridos a áridos, onde se verificam freqüentes adelgaçamentos ou descontinuidades laterais de estratos, ainda que constituam depósitos coetâneos e cogenéticos. Paleossolos e pavimentos de deflação, por exemplo, encontrados em diversas unidades, não se prestaram a correlações. O preenchimento da Bacia Bauru foi acompanhado por progressiva expansão dos limites da área deposicional, devido ao contínuo aporte de sedimentos das bordas e conseqüente colmatação do interior da bacia, apenas acentuado nos períodos de maior atividade tectônica dos altos marginais.

A análise estratigráfica de sequiências continentais, fundamentado em estudos de fácies e suas associações, como o realizado para a seqüência neocretácea, confronta-se com limitações conceituais, visto que as definições da aloestratigrafia aplicam-se melhor em sequiências de ambientes marinhos, além de limitações formais, pelo que estabelece o código brasileiro vigente. Por tais motivos, julgou-se mais adequado apresentar uma revisão de caráter litoestratigráfico. Ressaltase, porém, que variações de fácies e ambientes foram critérios discriminatórios importantes.

Agradecimentos Ao apoio financeiro da Fundação do Amparo à Pesquisa do Estado de São Paulo (processo FAPESP: 93/4524-9), aos professores Dr. Sidnei Pires Rostirolla (UFPR) e Dr. Mário Assine (UNESP), assim como aos revisores anônimos da RBG pela leitura crítica e sugestões ao original.

\section{Referências}

Almeida F.F.M. \& Barbosa O. 1953. Geologia das quadrículas Piracicaba e Rio Claro, Estado de São Paulo. Boletim DGM/DNPM, 143:1-96.

Almeida M.A., Stein D.P., Melo M.S., Bistrichi C.A., Ponçano W.L., Hasui Y., Almeida F.F.M. 1980. Geologia do Oeste Paulista e áreas fronteiricas dos estados de Mato Grosso do Sul e Paraná. In: SBG, Congresso Brasileiro de Geologia, 31, Camboriú, Anais, 5:2799-2812.

Barbosa O., Braun O.P.G., Dyler R.C., Cunha C.A.B.R. 1970. Geologia da região do Triângulo Mineiro. Boletim DGM/DNPM, 136:1-140.

Barcelos J.H. 1984. Reconstrução paleogeográfica da sedimentação do Grupo Bauru baseada na sua redefinição estratigráfica parcial em territónio paulista e no estudo preliminar fora do Estado de São Paulo. Inst. de Geociências e Ciências Exatas, preliminar fora do Estado de São Pallo., Inst. de Geociências e Ciências

Barcelos J.H. \& Suguio K. 1987. Correlação e extensão das unidades litoestratigráficas do Grupo Bauru definida em território paulista, nos estados de Minas Gerais, Goiás, Mato Grosso do Sul e Paraná. In: SBG/Núcleo SP, Simpósio Regional de Geologia, 6, Rio Claro, Atas, 1:313-321.

Barcelos J.H., Landim P.M.B., Suguio K. 1981. Análise estratigráfica das seqüências cretácicas do Triângulo Mineiro (MG) e suas correlações com as do Estado de São Paulo. In: SBG/Núcleo SP, Simpósio Regional de Geologia, 3, Curitiba, Atus, v.2:90102.

Bigarella J.J. \& Mazuchowski J.Z. 1985. Visão integrada da problemática da erosão. In: ABGE/ADEA, Simpósio Nacional de Controle da erosão, 3, Maringá, Livro guia, Maringá,. 232p.

Boggiani P.C. \& Coimbra A.M. 1996. A planície e os pantanais. In: Antas, P.T.Z. \& Nascimento, I.L.S. Tuiuiu. Sob os céus do Pantanal. São Paulo, Empresa das Artes, 18 23.

Brandt Neto M. 1977. Estratigrafía da Formação Bauru na região do baixo Tietê. São Paulo. Inst. de Geociências, Universidade de São Paulo, São Paulo, Dissertação de Mestrado, $74 \mathrm{p}$

Capilla R. \& Azevedo S.A.K. 1996. O Cretáceo da regiāo de Uberaba - Paleovertebrados. Roteiro de excursäo. Rio de Janeiro, Museu Nacional/UFRJ, 4 lp.

Coimbra A.M., Fernandes L.A., Hachiro J. 1992. Sismitos do Grupo Caiuá (Bacia Bauru, Ks) no Pontal do Paranapanema (SP). In: SBG, Congresso Brasileiro de Geologia 37, Săo Paulo, Boletim de Restumos Expandidos, v2:503-504.

Coimbra A.M., Coutinho J.M.V., Brandt Neto M., Rocha G.A. 1981. Lavas fonolíticas associadas ao Grupo Bauru no Estado de São Paulo. In: SBG/Núcleo SP, Simpósio Regional de Geologia, 3, Curitiba, Atas, 1:324-327.

Coutinho J.M.V., Coimbra A.M., Brandt Neto M., Rocha G.A. 1982. Lavas alcalinas analcimíticas associadas ao Grupo Bauru (Kb) no Estado de São Paulo, Brasil. In: Servicio Geológico Nacional, Congreso Latinamericano de Geologia, 5, Buenos Aires, Actas, 2:185-195.
Etchebehere M.L.C., Saad A.R., Taddeo J.S.A., Hellmeister Jr. Z. 1991. Moldes de cristais salinos no Grupo Bauru, Estado de São Paulo: implicações econômicas e paleoclimáticas. Geociências, 10:101-117

Fernandes L.A. 1998. Estratigrafia e evolução geológica da parte oriental da Bacia Bauru (Ks, Brasil). Inst. de Geociências, Universidade de São Paulo, São Paulo, Tese de Doutoramento, $216 \mathrm{p}$. (3 mapas)

Fernandes L.A., Coimbra A.M. 1992. A Cobertura cretácea suprabasáltica no Estado do Paraná e Pontal do Paranapanema (SP): os grupos Bauru e Caiuá. In: SBG. Congresso Brasileiro de Geologia, 37, São Paulo, Boletim de Resumos Expandidos, 2:506508 .

Fernandes L.A. \& Coimbra A.M. 1994. O Grupo Caiuá (Ks): revisão estratigráfica e contexto deposicional. Rev. Bras. Genciências, 24(3):164-176.

Fernandes L A \& Coimbra A.M. 1996. A Bacia Bauru (Cretáceo Superior, Brasil). Anais da Academia Brasileira de Ciências, 68(2):195-205.

Fernandes L.A. \& Coimbra A.M. 1998. Estratigrafia e evolução geológica da Bacia Bauru (Ks, Brasil). In: SBG, Congresso Brasileiro de Geologia, 40, Belo Horizonte, Anais, 101

Fernandes L.A., Coimbra A.M., Hachiro J. 1992. Ventifactos da Litofácies Mairá, Formação Santo Anastácio (Grupo Bauru, Ks). In: SBG, Congresso Brasileiro de Geolo gia, 37, São Paulo, Boletim de Resumos Expandidos, 2: 504-506.

Fernandes L.A., Coimbra A.M., Brandt Neto M. 1993. Silicificaçăo hidrotermal neocretáce na porção meridional da Bacia Bauru. Revista do Instituto Geológico, 14(2):19-26.

Ferreira Jr. P.D. \& Castro P.T.A. 1996. Análise de elementos arquiteturais em sistemas aluviais: o exemplo da Formação Uberaba (K, Bacia do Paraná) no Triângulo Mineiro, MG. In: SBG, Congresso Brasileiro de Geologia, 34, Salvador, Anais, 1:270-272.

Fúlfaro V.J., Perinotto J.A.J., Barcelos J.H. 1994. A margem goiana do Grupo Bauru: inplicações na litoestratigrafia e paleogeografia. In: UNESP, Simpósio sobre o Cretáceo do Brasil, 3, Rio Claro, Boletim, 81-4.

Goldberg K. 1995. Reconstituição paleoambiental do cretáceo continental brasileiro na região do Triângulo Mineiro. Universidade do Vale do Rio dos Sinos, São Leopoldo, Dissertação de Mestrado, $181 \mathrm{p}$.

Goldberg K. \& Garcia A.J.V. 1995. Faciologia dos calcários do Grupo Bauru na região de Uberaba (MG). Geociências, 14(2):121-131.

Gomes C.B. \& Valarelli J.V. 1970. Nova ocorrência de rochas alcalinas no Estado de São Paulo. In: SBG, Congresso Brasileiro de Geologia, 24, Brasília, Resunto das conferênciass e comunicaçoes, 336-337.

Hasui Y. 1967. Geologia das formações cretáceas do oeste de Minas Gerais. Escola Politécnica, Universidade de São Paulo, São Paulo, Tese de Doutoramento, 87p

Hasui Y. 1968. A Formação Uberaba. In: SBG, Congresso Brasileiro de Geologia, 22, Belo Horizonte, Anais, 167-179. 
Hasui Y. \& Haralyi N.L.E. 1991. Aspectos lito-estruturais e geofísicos do soerguimento do Alto Paranaíba. Geociências, 10:57-77.

Huene F von 1939 Carta de F von Huene ao Dr Euzébio de Oliveira. Mineração e Metaurgia, 4(22):190

Pereira M.J. \& Feijó F.J. 1994. Bacia de Santos. Boletim Geociências Petrobrás, 8(1):219-

Petri S., Coimbra A.M., Amaral G., Ojeda y Ojeda H., Fúlfaro V.J., Ponçano W.L. 1986. Código Brasileiro de Nomenclatura Estratigráfica. Rev. Bras. Geociências, 16(4):372-6

Pinotti R.F., Corsini P.C., Madureira Filho J.B., Valarelli J.V. 1970. Levantamento de solos contribuindo para a descoberta geológica. In: SBG, Congresso Brasileiro de Geoloia 24, Brasília Resumo das conferências e comunicacōes, 59-60.

Ponçano WIL Stein D.P Almeida FFM Almeida M.A. Melo M.S. 1982. A Formação Itaqueri e depósitos correlatos no Estado de São Paulo. In: SBG, Congresso BrasiItaqueri e depositos correlatos no Estado de Săo Paiso.

Silva R B. Etchebehere M.L.C. Saad A 1994. Groundwater calcretes: uma interpretação alternativa para os calcários da Formaçăo Marília no Triângulo Mineiro. In: UNESP, alternativa para os calcários da Formaçáo Marilia no Trângulo Mine

Soares P.C ósio sobre o Cretáceo do V. So , R.ro Neto A.F. 1980 . Ensaio de caracterização do Cretáceo no Estado de São Paulo: Grupo Bauru. Rev. Bras. Geociências, 10(3): $177-185$

Stein D.P., Melo M.S., Bistrichi C.A., Almeida M.A., Hasui Y., Ponçano W., Almeida F.F.M. 1979. Geologia de parte dos vales dos rios Paraná e Paranapanema. In: SBG/ Núcleo SP, Simpósio Regional de Geologia, 2, Rio Claro, Atas, 2:291-306.

Suguio K. 1973. Formaçāo Bauru: calcários e sedimentos detríticos associados. Inst. de Geociências, Universidade de São Paulo São Paulo, Tese de Livre-Docência, 2v.
Suguio K. 1981. Fatores paleoambientes e paleoclimáticos e subdivisão estratigráfica do Grupo Bauru. In: , SBG/Núcleo SP, Mesa Redonda: A Formação Bauru no Estado de São Paulo e Regiōes Adjacentes, São Paulo, Coletânea de frabalhos e debates, 15-26.

Suguio K \& Barcelos J H 1978. Nota sobre a ocorrência de atapulgita em sedimentos do Grupo Bauru, Cretáceo Superior da Bacia do Paraná. In: SBG, Congresso Brasileiro Grupo Bauru, Cretáceo Superior da Bacia do Paraná. In: SBG, Congresso Brasileiro

Suguio K., Berenholc M., Salati E. 1975. Composição química e isotópica dos calcários e mbiente de sedimentação da Formação Bauru. Boletim IG, 6:55-75.

Suguio K., Fúlfaro V.J., Amaral G., Guidorzi L. A. 1977. Comportamentos estratigráficos e estrutural da Formação Bauru nas regiôes administrativas 7 (Bauru), 8 (Săo José do Rio Preto) e 9 (Araçatuba) no Estado de São Paulo. In: SBG/Núcleo SP, Simpósio de Geologia Regional, 1, São Paulo, Atas, 231-247.

Watts N.L. 1978. Displacive calcite: evidence from recent and ancient calcretes. Geology, 6:699.703.

Zaine J.E et al 1980. Geologia do Bloco 38; regiäo de Aracatuba/Tupã. São Paulo. Paulipetro (Consórcio CESP/IPT), Rel. BP-014/80. 2v. (Inédito)

Manuscrito A-1129

Recebido em 21 de outubro de 1999

Revisão dos autores em 20 de maio de 2000 Revisão aceita em 30 de maio de 2000 